\title{
Disentangling Diverse Measures: A Survey of Financial Stress Indexes
}

\author{
$\underline{\text { Kevin L. Kliesen, Michael T. Owyang, and E. Katarina Vermann }}$
}

\begin{abstract}
The recent financial crisis helped emphasize the need for measures of financial conditions. In the wake of the crisis, several researchers and institutions-both private sector and central bank-developed measures of financial stress. These measures are intended to capture, among other things, the liquidity in financial markets and potentially forecast changes in real economic conditions. Unfortunately, there is no agreement about which variables should be included in a measure of stress. The authors survey a number of financial stress indexes, comparing the datasets from which they are constructed. In principle, each of the indexes measures the same thing; thus, they should be highly correlated. The authors find that in practice, however, the correlations are high but not as high as might be expected. They also evaluate the ability of the indexes to predict future economic activity in a simple vector autoregressive forecasting model. (JEL E44, E66)
\end{abstract}

Federal Reserve Bank of St. Louis Review, September/October 2012, 94(5), pp. 369-97.

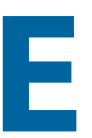

conomists recognize that adverse shocks to the financial sector can have significant effects on the real economy. The chance that financial instability will lead to macroeconomic instability is often termed "systemic risk." For example, in 2008, policymakers learned that financial market turmoil resulting from the bankruptcy of Lehman Brothers and the near-failure of American International Group (AIG) had far-reaching effects on the macroeconomy through asset prices and other key financial market indicators. ${ }^{1}$

The recent financial crisis and subsequent recession provide another example of these effects. If financial crises could be predicted ahead of time, policymakers might have an opportunity to mitigate the damages - or perhaps avoid them altogether. Historically, though, policymakers have been unable to predict such crises, in part because they have lacked proper indicators of financial instability.

One of the key "take-away" messages for policymakers from the 2007-08 experience is that predicting financial crises ex ante remains extraordinarily difficult. This task is perhaps made more difficult because financial crises often take different forms and are triggered by qualitatively different shocks. $\underline{2}$

Kevin L. Kliesen and Michael T. Owyang are research officers and economists and E. Katarina Vermann is a research associate at the Federal Reserve Bank of St. Louis. The authors thank Linpeng Zheng for research assistance.

(c) 2012, The Federal Reserve Bank of St. Louis. The views expressed in this article are those of the author(s) and do not necessarily reflect the views of the Federal Reserve System, the Board of Governors, or the regional Federal Reserve Banks. Articles may be reprinted, reproduced, published, distributed, displayed, and transmitted in their entirety if copyright notice, author name(s), and full citation are included. Abstracts, synopses, and other derivative works may be made only with prior written permission of the Federal Reserve Bank of St. Louis. 


\section{Selected Abbreviations}

$\begin{array}{ll}\text { ADS } & \text { Arouba-Diebold-Scotti Business Conditions Index } \\ \text { ANFCI } & \text { Federal Reserve Bank of Chicago Adjusted NFCI } \\ \text { BFCI } & \text { Bloomberg Financial Conditions Index } \\ \text { CFSI } & \text { Federal Reserve Bank of Cleveland Financial Stress Index } \\ \text { CISS } & \text { Composite Indicator of Systemic Stress (Europe) } \\ \text { CLNFCI } & \text { Carlson, Lewis, and Nelson (2012) Financial Condition Index } \\ \text { GSFCI } & \text { Goldman Sachs Financial Conditions Index } \\ \text { IMFFSI } & \text { International Monetary Fund Advanced Economies Financial Stress Index } \\ \text { KCFSI } & \text { Federal Reserve Bank of Kansas City Financial Stress Index } \\ \text { MAFCI } & \text { Macroeconomic Advisers' Monetary and Financial Conditions Index } \\ \text { NFCI } & \text { Federal Reserve Bank of Chicago National Financial Conditions Index } \\ \text { STLFSI } & \text { Federal Reserve Bank of St. Louis Financial Stress Index } \\ \text { VIX } & \text { Chicago Board Options Exchange Market Volatility Index }\end{array}$

In their efforts to address this shortcoming, economists have developed an array of statistical indicators designed to measure financial instability (see the boxed insert). These indexes are often termed "financial stress indexes" (FSIs) or "financial conditions indexes" (FCIs) depending on the variables used to construct them. In reality, though, financial stress cannot be measured like other economic indicators (e.g., gross domestic product [GDP] or employment), which count tangible objects such as workers, jobs, or the value of production. Instead, these indexes measure latent conditions and are constructed from other economic and/or financial data using sophisticated statistical techniques long in use by economists and statisticians.

Economic policymakers also have a vested interest in measuring financial instability. In the United States, measuring financial stress to help identify emerging systematic risks has been enshrined in the Dodd-Frank Wall Street Reform and Consumer Protection Act of 2009. Among a myriad of other provisions, this act established the Financial Stability Oversight Council (FSOC) and the Office of Financial Research (OFR). Since the FSOC consists of the heads of the nation's key regulatory agencies (e.g., the Federal Reserve, the Federal Deposit Insurance Corporation, and the Securities and Exchange Commission), its mandate is to prevent financial stresses from propagating into systemic threats, thereby negatively affecting economic growth and material welfare (Lo Duca and Peltonen, 2011). Together the FSOC and the OFR can be viewed as a key part of the nation's real-time early warning system for policymakers.

As intimated above, measuring financial conditions and identifying emerging threats to financial stability is difficult. Because no single consensus definition, let alone measure, of financial stress exists, one goal of this paper is to describe how financial instability has been measured in the literature. Admittedly, the literature is becoming increasingly populated with articles that survey the available indicators and attempt to assess their reliability. These include papers by Hatzius et al. (2010), Hollo et al. (2012), and Oet et al. (2011, the Federal Reserve Bank of Cleveland's FSI [CFSI]). Although this paper is in the spirit of the preceding survey articles, we aim to provide a perspective that is more readily accessible to a nonacademic audience. Analyzing 
the construction of various FSIs allows us to assess whether they are useful real-time indicators of the state of the economy.

We consider a number of U.S. and international financial indexes. A second goal of our paper is to empirically assess both the correlation of these indexes-for example, whether there is significant co-movement across the indexes-and their predictive power. Regarding the latter point, we seek to determine whether these indexes can accurately predict economic and financial activity, as measured by the growth of industrial production, real GDP, and U.S. equity prices as measured by the Wilshire 5000 .

The rest of the paper is outlined as follows. The following section discusses the definition of financial stress and how it is measured. In this section, we also clarify the relationship among financial stress, FSIs, and FCIs. Next we review a number of international FSIs. The following section compares the different indexes and considers how well they predict macroeconomic variables. The last section provides our conclusions.

\section{FINANCIAL STRESS INDEXES VERSUS FINANCIAL CONDITIONS INDEXES}

Financial markets are inherently forward-looking. Economic shocks that cause financial market participants to revise their expectations of future returns are quickly embedded in current asset prices and then transmitted into the rest of the financial sector and the real economy. Financial stress may increase if conditions change because of one of these shocks. While financial stress is universally viewed as negative, the term itself is subject to various definitions and interpretations (Table 1). To economists and those active in financial markets, financial stress might be thought of as an increase in the probability of default on a security, such as a corporate bond.

For bonds, stress is reflected in interest rates on debt securities with different default risks or in an increase in volatility measures constructed with options prices. One common measure of stress is an interest rate spread, such as that between the interest rate on so-called risk-free debt (U.S. Treasury securities) and interest rates on so-called risky securities, such as a composite yield on corporate investment- or speculative-grade bonds. For stocks, expectations of lower earnings or smaller dividends are reflected in their prices. $\frac{3}{-}$

Measures of aggregate financial stress would summarize sets of these probabilities for broad categories of products or markets. Following Abdymomunov (2012), we define market-level financial stress as a mix of conditions, in which "market participants experience increased uncertainty or change their expectations about future financial losses, fundamental value of assets, and economic activity" (p. 2). This definition implies that financial stress is a multidimensional problem: It involves a number of (simultaneous or temporally proximate) exogenous shocks to factors from banks and financial markets. Rather than measuring these factors/shocks directly, an FSI looks for evidence of these shocks. Thus, the level of the FSI indicates the interaction of financial vulnerabilities and the size of shocks (Grimaldi, 2010, 2011); extreme values occur in times of panic/crashes/crises.

In general, FSIs try to monitor financial instability by creating a time series of values in which increases indicate the increased likelihood of a crisis. The data that comprise these indexes tend to contain information on spreads, correlations, and interest rates, some of which have been aggregated first into subindexes and then into the final FSI measure. FCIs, on the other 


\section{Kliesen, Owyang, Vermann}

\section{Table 1}

\section{Definitions of Financial Stress and/or What Each Index Seeks to Measure}

Index

$\mathrm{BFCl}$ (Rosenberg, 2009)

Grimaldi $(2010,2011)$

Danninger et al. (2009)

Lo Duca and Peltonen (2011)

Cardarelli, Elekdag, and Lall (2011)

Nelson and Perli (2007)

Brave and Butters $(2011,2012)$

Carlson, Lewis, and Nelson (2012)

Illing and Liu (2006)

\section{Definition}

"Tracks the overall stress in the U.S. money market, bond market, and equity market and provides a useful gauge to assess the availability and cost of credit in the U.S. financial market" (p. 12).

"How far trends in U.S. money-market spreads, bond-market spreads, and key equitymarket indicators are deviating from historical normal" (p. 10).

"Stress is the product of vulnerable markets and shocks...we can think of the level of stress as being determined by the interaction between financial vulnerabilities and the size of shocks. The more fragile financial conditions are, i.e. the more vulnerable markets are, the more likely a shock is to result in stress" (p. 4).

No clear definition, but signs of stress include "financial turmoil," "exchange rates under pressure, leading to a combination of depreciation and depletion of foreign reserves," "dwindling capital inflows," "withdrawals from emerging economy equity and debt funds," and "bank lending was scaled back."

Systemic risk: "[E]vents when financial instability becomes so widespread that it impairs the functioning of the financial system to the extent that economic growth and welfare suffer materially" (p. 6).

"Episodes of extreme financial stress that [have] led to negative real economic consequences on average" (p. 6).

"Extreme values of a composite variable...built using market-based indicators in real time and high frequency" (p. 80).

Financial instability that "can impede economic activity and reduce economic welfare"; signs: dysfunctional financial markets, strained key institutions.

Financial instability.

Markets that are not "functioning or behaving in a typical fashion" (p. 3); "impaired functioning might take the form of increased difficulty in executing transactions or an inability of intermediaries to fund their market-making operations at usual tenors. Fragility might take the form of exceptionally heightened sensitivity to new information or shocks" (p. 12).

"Stress increases with expected financial loss, with risk (a widening in the distribution of probable loss), or with uncertainty (lower confidence about the share of the distribution of probable loss)" (p. 2).

hand, tend to use other types of financial and nonfinancial variables to measure financial instability. Although Table 2 indicates considerable overlap between FCIs and FSIs, the primary difference is that the former tend to contain quantities, prices, and economic indicators, whereas the latter generally use only prices. For example, Hatzius et al. (2010) use measures of bank credit, debt, asset-backed securities, and surveys of consumers and small businesses. In addition, some FCIs-such as the Macroeconomic Advisers (2003) Monetary and Financial Conditions Index (MAFCI) - are designed to map directly into changes in real GDP (e.g., an X-percent change in financial conditions corresponds to a Y-percentage-point change in future real GDP). Thus, FCIs tend to encompass a larger universe of financial variables. In some cases, they are described in terms of deviations from long-term trends. 
Table 1, cont'd

\section{Definitions of Financial Stress and/or What Each Index Seeks to Measure}

Index

Oet et al. (2011)

Hollo, Kremer, and Lo Duca (2012)

Louzis and Vouldis (2011)

Abdymomunov (2012)

Hansen (2006)

Hanschel and Monnin (2005)

Sandahl et al. (2011)

Hakkio and Keeton (2009)

Morales and Estrada (2010)

\section{Definition}

"Two consecutive weeks of market volatility above the previous quarterly thresholds, or concurrent volatility in at least two distinct markets" (p. 32).

"The current state of instability, i.e. the current level of frictions, stresses and strains (or the absence of these) in the financial system" (p. 3).

Systemic stress = the "amount of systemic risk which has materialized, systemic risk, in turn, can be defined as the risk that financial instability becomes so widespread that it impairs the functioning of a financial system to the point where economic growth and welfare suffer materially" (p. 4).

"A condition of financial markets when market participants experience increased uncertainty or change their expectations about future financial losses, fundamental value of assets, and economic activity" (p. 1).

Risk

"The current condition of the Swiss banking sector" (p. 431).

"The stress indicator represents a continuum of states which describe the banking sector's condition at a given point in time...stress emerges from the combination of exogenous shocks and fragilities in the banking system" (p. 432).

"A disruption that impairs the financial markets' ability to act as an efficient intermediary between lender and borrower or buyer and seller. By efficient, we mean that there is good market liquidity and an even distribution of information between the agents in the market" (p. 51).

A period that is characterized by at least one of the following five circumstances: uncertainty over the fundamental value of financial assets, uncertainty over other investors' behavior, information asymmetries, substantially increased demand for assets with very low risk (flight to quality), and substantially increased demand for assets with very good liquidity (flight to liquidity).

Bank profitability and probability of default.

An FCI can also be used to predict changes in economic business cycles. As such, an FSI can be considered a snapshot of the level of fragility in the financial market and an FCI a mapping of financial conditions onto macroeconomic conditions (Carlson, Lewis, and Nelson, 2012; CLNFCI). In this sense, FSIs have "no natural observable counterpart in the real world" (Louzis and Vouldis, 2011, p. 3) and can only be measured relative to themselves, while FCIs assume a relationship between the financial sector and an element of the macroeconomy. Given their design, then, these types of FCIs might be expected to be better predictors of real economic activity.

The first step in gauging the cyclical properties of each type of index, as well as their comovement (if any), is to plot an FSI and an FCI. Figure 1 plots two measures: the Federal Reserve Bank of St. Louis Financial Stress Index (STLFSI; Kliesen and Smith, 2010) and the Federal Reserve Bank of Chicago National Financial Conditions Index (NFCI; Brave and Butters, 2011). The two measures moved rather closely together before 2000 and from 2007 to the present, but 


\section{Kliesen, Owyang, Vermann}

\section{Table 2}

\section{U.S. Index Variables}

\begin{tabular}{|c|c|c|c|c|c|c|c|c|c|c|c|}
\hline \multirow[b]{2}{*}{ Indicator } & \multicolumn{11}{|c|}{ Indexes } \\
\hline & 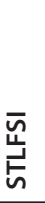 & $\begin{array}{l}\bar{U} \\
\text { 岂 }\end{array}$ & प्u & 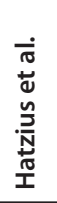 & $\begin{array}{l}\infty \\
\stackrel{\sim}{4}\end{array}$ & 氙 & 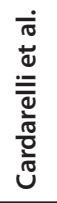 & ज̆ & 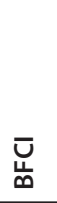 & ড্ডু & 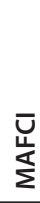 \\
\hline \multicolumn{12}{|l|}{ Fundamentals } \\
\hline (Effective) Federal funds rate & $x$ & & & & & & & & & & $x$ \\
\hline \multicolumn{12}{|l|}{ Federal funds rate - 3-month Treasury spread } \\
\hline Federal funds rate - Repo rate spreads & & & $\mathrm{x}$ & & & & & & & & \\
\hline Federal funds rate - 2-year Treasury yield spread & & $\mathrm{x}$ & & & $x$ & & & & & & \\
\hline Federal funds rate - 3-month Treasury yield spread & & & & & $x$ & & & & & & \\
\hline LIBOR - Federal funds target rate spread & & & $x$ & & & $x$ & & & & & \\
\hline 1-year - 1-month LIBOR spread & & & $x$ & & & & & & & & \\
\hline Real 3-month LIBOR & & & & & & & & & & $x$ & \\
\hline 10-year nominal Treasury - TIPS yield spread & $\mathrm{x}$ & & & & & & & & & & \\
\hline 3-month Eurodollar - U.S. Treasury spread & & & $x$ & & & & & & & & \\
\hline 3-month Eurodollar confidence interval, 1 year ahead & & & & & $x$ & & & & & & \\
\hline Money (M1) stock & & & & $\mathrm{x}$ & & & & & & & \\
\hline Oil prices & & & & $x$ & & & & & & & \\
\hline \multicolumn{12}{|l|}{ Foreign exchange } \\
\hline $\begin{array}{l}\text { Covered interest spread from various U.S.-U.K. } \\
\text { Treasury bill rates }\end{array}$ & & & & & & $\mathrm{x}$ & & & & & \\
\hline FRB broad nominal exchange rate & & & & & & & & & & & $\mathrm{x}$ \\
\hline Real Goldman Sachs Trade-Weighted Dollar Index & & & & & & & & & & $x$ & \\
\hline Time-varying exchange rate volatility: GARCH(1,1) & & & & & & & $\mathrm{x}$ & & & & \\
\hline $\begin{array}{l}\text { Weighted dollar crashes calculated from trade- } \\
\text { weighted U.S. exchange index: Major currencies }\end{array}$ & & & & & & $\mathrm{x}$ & & & & & \\
\hline \multicolumn{12}{|l|}{ Quality premium } \\
\hline $\begin{array}{l}\text { (12-month-ahead S\&P earnings/S\&P prices) - 10-year } \\
\text { Treasury yield spread }\end{array}$ & & $x$ & & & $x$ & & & & & & \\
\hline $\begin{array}{l}\text { 3-month commercial paper rate - 3-month Treasury } \\
\text { spread }\end{array}$ & $\mathrm{x}$ & & & & & & & & $\mathrm{x}$ & & \\
\hline $\begin{array}{l}\text { 90-day commercial paper rate - 3-month Treasury } \\
\text { secondary market rate spread }\end{array}$ & & & & & & $\mathrm{x}$ & & & & & \\
\hline $\begin{array}{l}\text { 1-month nonfinancial commercial paper rate - AA credit } \\
\text { spread }\end{array}$ & & & $x$ & & & & & & & & \\
\hline 10-year A bank bond index - 10-year Treasury yield spread & & & & & & $\mathrm{x}$ & & & & & \\
\hline AA bond - Treasury security spread & & $x$ & & & $x$ & & & & & & \\
\hline AAA corporate bond - 10-year Treasury yield spread & & & & & & $\mathrm{x}$ & & $x$ & & & \\
\hline Agency - Treasury spread & & & & & & & & & $\mathrm{x}$ & & \\
\hline Baa corporate bond - 10-year Treasury yield spread & $\mathrm{x}$ & & $\mathrm{x}$ & $x$ & & & & & & & \\
\hline Baa - Aaa corporate bond spread & & & & & & & & $x$ & & & \\
\hline
\end{tabular}


Table 2, cont'd

\section{U.S. Index Variables}

\begin{tabular}{|c|c|c|c|c|c|c|c|c|c|c|c|}
\hline \multirow[b]{2}{*}{ Indicator } & \multicolumn{11}{|c|}{ Indexes } \\
\hline & 岀 & $\begin{array}{l}\bar{U} \\
\text { ư } \\
\text { U }\end{array}$ & $\overline{\mathrm{U}}$ & 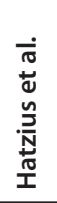 & $\underset{\mathscr{q}}{\mathscr{q}}$ & $\overline{\tilde{u}}$ & 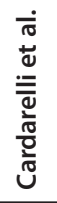 & $\overline{\bar{n}}$ & 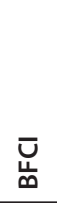 & $\begin{array}{c}\bar{u} \\
\text { ড̦ }\end{array}$ & 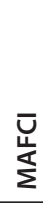 \\
\hline BBB bond rate - Treasury rate spread & & $x$ & & & $x$ & & & & & & \\
\hline $\begin{array}{l}\text { Bond Market Association municipal swap index - 20-year } \\
\text { Treasury yield spread }\end{array}$ & & & $x$ & & & & & & $\mathrm{x}$ & & \\
\hline $\begin{array}{l}\text { Corporate bond yield - Long-term government bond } \\
\text { yield spread }\end{array}$ & & & & & & & $\mathrm{x}$ & & $\mathrm{x}$ & & \\
\hline Correlation of returns on equities and Treasury securities & & & & $\mathrm{x}$ & & & & & & & \\
\hline Stock - bond correlation & & & & & & & & $x$ & & & \\
\hline Merrill Lynch U.S. High-Yield Master II Index & $x$ & & & & & & & & & & \\
\hline $\begin{array}{l}\text { Merrill Lynch U.S. High-Yield Master II Bond Index - Baa } \\
\text { spread }\end{array}$ & & & $\mathrm{x}$ & $\mathrm{x}$ & & & & $\mathrm{x}$ & & & \\
\hline $\begin{array}{l}\text { Merrill Lynch U.S. High-Yield Master II Index - 10-year } \\
\text { Treasury spread }\end{array}$ & $\mathrm{x}$ & & & & & & & & $\mathrm{x}$ & & \\
\hline $\begin{array}{l}\text { 7-year high-yield corporate bond - Treasury security } \\
\text { spread }\end{array}$ & & $x$ & & & $x$ & & & & & & \\
\hline Total market capitalization-to-nominal GDP ratio & & & & & & & & & & $\mathrm{x}$ & \\
\hline \multicolumn{12}{|l|}{ Equity markets } \\
\hline Broker-dealer debit balances in margin accounts & & & & $x$ & & & & & & & \\
\hline Broker-dealer leverage & & & $x$ & $x$ & & & & & & & \\
\hline Credit Derivatives Research Counterparty Risk Index & & & $x$ & & & & & & & & \\
\hline Change in stock index & & & & & & & $\mathrm{x}$ & & & & \\
\hline Citigroup financial - Corporate credit bond spread & & & $x$ & & & & & & & & \\
\hline Cross-section dispersion of bank stock returns & & & & & & & & $x$ & & & \\
\hline Financial beta & & & & & & $x$ & $x$ & & & & \\
\hline Financial market cap & & & & $\mathrm{x}$ & & & & & & & \\
\hline JP Morgan Emerging Market Bond Index & $\mathrm{x}$ & & & & & & & & & & \\
\hline Market capitalization & & & $x$ & & & & & & & & \\
\hline S\&P 500 Share prices & & & & & & & & & $\mathrm{x}$ & & \\
\hline S\&P Financials-to-S\&P prices ratio & & & $x$ & & & & & & & & \\
\hline Dividend-to-price ratio & & & & & & & & & & & $\mathrm{x}$ \\
\hline Stock market crashes using S\&P 500 Financials & & & & & & $x$ & & & & & \\
\hline Vanguard Financials Exchange-Traded Fund (equities) & $\mathrm{x}$ & & & & & & & & & & \\
\hline Wilshire 5000 & & & $x$ & $\mathrm{x}$ & & & & & & & \\
\hline \multicolumn{12}{|l|}{ Term premium } \\
\hline 10-year Treasury - 2-year Treasury spread & & & & & & & & & & & \\
\hline 10-year Treasury - 3-month Treasury spread & $\mathrm{x}$ & & & $x$ & & & & & & & \\
\hline $\begin{array}{l}10 \text {-year commercial paper - 3-month commercial paper } \\
\text { rate spread }\end{array}$ & & & & & & & & & & & \\
\hline
\end{tabular}




\section{Kliesen, Owyang, Vermann}

\section{Table 2, cont'd}

\section{U.S. Index Variables}

Indicator

\begin{tabular}{|c|c|c|c|c|c|c|c|c|c|c|}
\hline \multicolumn{11}{|c|}{ Indexes } \\
\hline \multirow[t]{6}{*}{ 苟 } & $\begin{array}{l}\bar{U} \\
\text { 崩 }\end{array}$ & $\begin{array}{l}\bar{u} \\
\text { L }\end{array}$ & $\begin{array}{l}\dot{0} \\
\stackrel{0}{0} \\
\\
\stackrel{N}{N} \\
\frac{N}{1}\end{array}$ & $\stackrel{\mathscr{q}}{\mathscr{\sim}}$ & 药 & $\begin{array}{l}\frac{\dot{0}}{0} \\
\stackrel{0}{0} \\
\overline{\overline{0}} \\
\frac{0}{0} \\
\frac{0}{0}\end{array}$ & $\begin{array}{l}\bar{n} \\
\ddot{u}\end{array}$ & 핌 & $\begin{array}{l}\bar{U} \\
\text { ज़ }\end{array}$ & $\underset{\bar{u}}{\bar{\Sigma}}$ \\
\hline & & & $x$ & & $x$ & & & & & \\
\hline & & $x$ & $x$ & & & & & & & \\
\hline & $x$ & & & & & & & & & \\
\hline & & $x$ & & & & & & & & \\
\hline & & & & & & $x$ & & & & \\
\hline
\end{tabular}

2-year swap spread

2-year swap - 2-year Treasury spread

2-year Treasury on-the-run premium

10-year swap - Treasury yield spread

Off-the-run - On-the-run 10-year Treasury spread

LIBOR - OIS spread

Repo market data

TED spread

Yields

2-year Treasury yield

10-year Treasury yield

30-year Treasury yield

Real A bond yield

Aaa corporate bond yield

Baa corporate bond yield

Citigroup corporate bond yields

Merrill Lynch Asset-Backed Master BBB-rated

Volatility

3-month Treasury bid-ask spread

Bank CDS spread

Idiosyncratic volatility of banking industry

Time-varying stock volatility: $\operatorname{GARCH}(1,1)$

Eurodollar implied volatility

Private long-term bond implied volatility

10-year Treasury bond implied volatility

Merrill Lynch Bond Market Volatility Index

Merrill Lynch Option Volatility Expectations

Merrill Lynch Swaptions Volatility Expectations
$\mathrm{X}$

\section{$\mathrm{X}$}

$\mathrm{x}$

$\mathrm{X}$

$x-x$

$x \quad x$

$x$

$\begin{array}{lllllllll} & x & x & x & x & x & x & x & x\end{array}$

X

$x \quad x \quad x$

$\mathrm{X}$

$x$

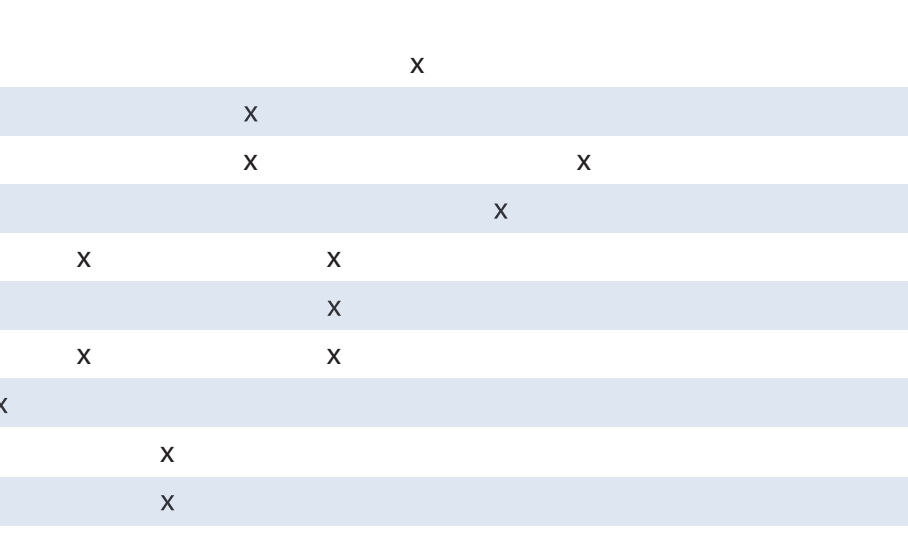


Table 2, cont'd

\section{U.S. Index Variables}

\begin{tabular}{|c|c|c|c|c|c|c|c|c|c|c|c|}
\hline \multirow[b]{2}{*}{ Indicator } & \multicolumn{11}{|c|}{ Indexes } \\
\hline & 范 & 㟧 & $\begin{array}{l}\bar{y} \\
\text { z }\end{array}$ & 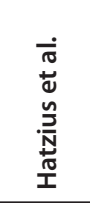 & $\underset{\mathscr{q}}{\stackrel{\mathscr{r}}{4}}$ & $\overline{\breve{u}}$ & 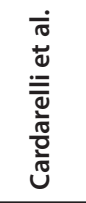 & $\overline{\bar{u}}$ & 핌 & $\begin{array}{l}\bar{U} \\
\text { ज़ }\end{array}$ & 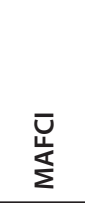 \\
\hline VIX (VXO) & $\mathrm{x}$ & $\mathrm{x}$ & $\mathrm{x}$ & $\mathrm{x}$ & $\mathrm{x}$ & & & $\mathrm{x}$ & $\mathrm{x}$ & & \\
\hline \multicolumn{12}{|l|}{ Consumer prices } \\
\hline $\begin{array}{l}\text { 30-year conventional mortgage - } 10 \text {-year Treasury rate } \\
\text { spread }\end{array}$ & & & & $\mathrm{x}$ & & & & & & & \\
\hline Mortgage rate spreads & & & & $x$ & & & & & & & \\
\hline 5-year AAA CMBS rate - Treasury spread & & & $\mathrm{x}$ & & & & & & & & \\
\hline Consumer ABS - Treasury spread & & & $\mathrm{x}$ & & & & & $x$ & & & \\
\hline MBS - 10-year Treasury yield spread & & & $\mathrm{x}$ & & & & & & & & \\
\hline Car loan interest rate - 2-year Treasury spread & & & & $\mathrm{x}$ & & & & & & & \\
\hline Personal loan interest rate - 2-year Treasury spread & & & & $\mathrm{x}$ & & & & & & & \\
\hline Perceived consumer credit conditions & & & $\mathrm{x}$ & $\mathrm{x}$ & & & & & & & \\
\hline Household equity net worth & & & & & & & & & & & $x$ \\
\hline Property price indexes & & & $x$ & $\mathrm{x}$ & & & & & & & \\
\hline \multicolumn{12}{|l|}{ Quantities } \\
\hline \multicolumn{12}{|l|}{ Bank deposits } \\
\hline \multicolumn{12}{|l|}{ Bank loans } \\
\hline Bank credit & & & & $x$ & & & & & & & \\
\hline Debt issuance & & & $x$ & $x$ & & & & & & & \\
\hline Debt outstanding & & & $x$ & $x$ & & & & & & & \\
\hline Commercial paper issuance & & & & $x$ & & & & & & & \\
\hline Commercial paper outstanding & & & $\mathrm{x}$ & $x$ & & & & & & & \\
\hline Private nonfinancial debt & & & & $x$ & & & & & & & \\
\hline Government liabilities & & & & $x$ & & & & & & & \\
\hline \multicolumn{12}{|l|}{ Other information } \\
\hline Number of indicators & 18 & 12 & 100 & 45 & 12 & 11 & 7 & 11 & 10 & 4 & 5 \\
\hline Start year & 1993 & 1994 & 1973 & 1970 & 1994 & 1990 & 1980 & 1990 & 1991 & 1990 & 1982 \\
\hline Frequency & W & $\mathrm{D}$ & M & Q & W & $\mathrm{D}$ & Q & M & $\mathrm{D}$ & $\mathrm{D}$ & Q \\
\hline $\begin{array}{l}\text { NOTE: D, Daily; M, monthly; Q, quarterly; W, weekly; ABS, asset- } \\
\text { commercial mortgage-backed securities; GARCH }(1,1) \text { general a } \\
\text { return and only one variance; MBS, mortgage-backed securitie } \\
\text { Volatility Index. }\end{array}$ & $\begin{array}{l}\text { backed } \\
\text { utoregre } \\
\text { s; repo, }\end{array}$ & $\begin{array}{l}\text { securiti } \\
\text { essive cc } \\
\text { repurch }\end{array}$ & $\begin{array}{l}\text { ies; } C D \text {, } \\
\text { onditio } \\
\text { hase ag }\end{array}$ & $\begin{array}{l}\text { certific } \\
\text { nally he } \\
\text { greemen }\end{array}$ & $\begin{array}{l}\text { cate of } d \\
\text { eteroske } \\
\text { nt; VXO, }\end{array}$ & $\begin{array}{l}\text { deposit; } \\
\text { edastic } r \\
\text { Chicag }\end{array}$ & $\begin{array}{l}\text { CDS, } \mathrm{cr} \\
\text { model } \mathrm{t} \\
\text { o Board }\end{array}$ & $\begin{array}{l}\text { redit de } \\
\text { that lags } \\
\text { d Option }\end{array}$ & $\begin{array}{l}\text { fault sw } \\
\text { s on onl } \\
\text { ns Excha }\end{array}$ & $\begin{array}{l}\text { wap; } C M \\
\text { ly one s } \\
\text { ange S\& }\end{array}$ & $\begin{array}{l}\text { ABS, } \\
\text { squared } \\
\& \mathrm{P} 100\end{array}$ \\
\hline
\end{tabular}




\section{Figure 1}

\section{St. Louis FSI and Chicago Fed NFCI}

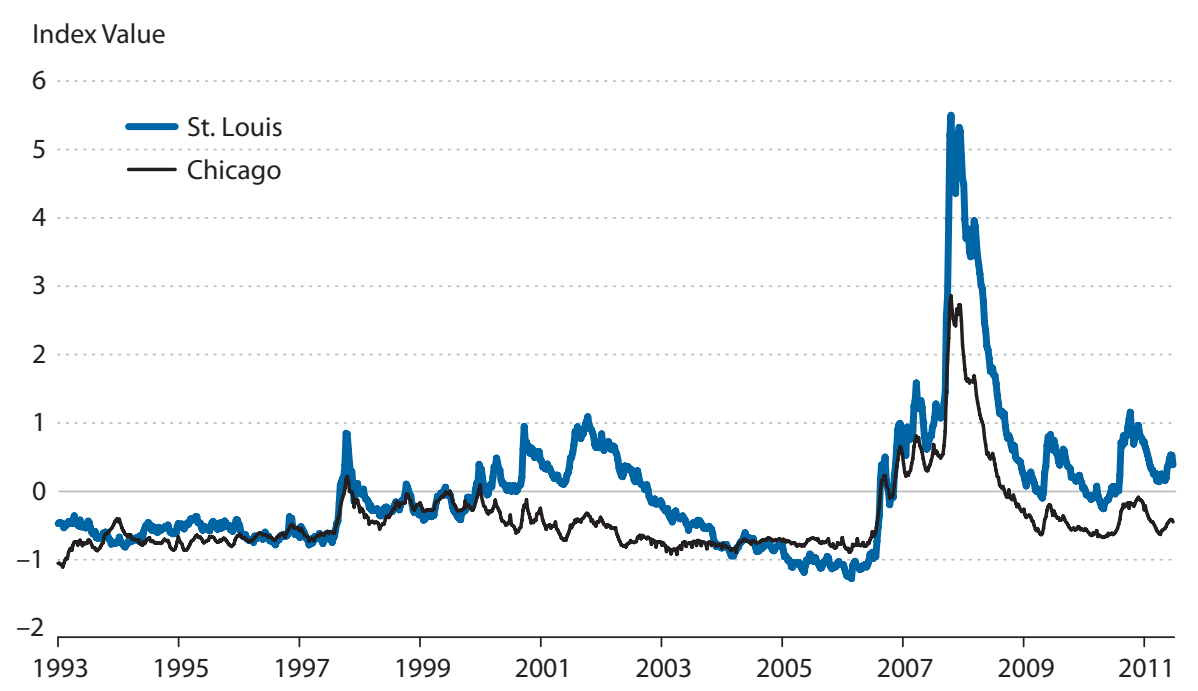

deviated considerably in the intervening years. Although the sample period correlation is quite high (0.90), it is also interesting that the NFCI has been below zero for a large percentage of the sample period. Although both measures indicated extremely high levels of stress in 2007-08, the STLFSI indicated heightened levels of stress for a longer period, in contrast with the NFCI. Further, the STLFSI indicated rising levels of stress (above 0) in 2000-01 and more recently in 2010-12 with the increase in financial market turmoil stemming from the sovereign debt crisis in Europe. In both cases, though, the indexes would predict expectations of weaker growth arising from an increase in the index.

\section{Index Construction: Data}

Researchers confront some trade-offs when examining which data to use to measure financial conditions. The first trade-off concerns time span. FSIs or FCIs with longer samples could be constructed using stock prices, exchange rates, and interest rates on Treasury and corporate bonds. The advantage of constructing a longer series is that its predictive properties, including its relationship to macroeconomic indicators, might be better tested over several business cycles. By contrast, using relatively new measures with limited history, such as overnight index swap rates, credit default swap spreads, or the London Interbank Offered Rate (LIBOR), might limit the historical content of the index. These newer measures, though, may be better measures of financial conditions and, in some cases, warrant sacrificing longer samples. Table 2 and Appendix A indicate that FSI start dates range from 1970 to 2000.

A second trade-off is related to the frequency (i.e., quarterly, monthly, weekly, or daily) at which the input data are observed. One potential advantage of using higher-frequency data is that they may better facilitate real-time decisionmaking. That is, to the extent that shocks can 
be more quickly identified with weekly data than monthly data, policymakers may be able to assess rapidly evolving economic conditions-such as in the fall of 2008-in a more timely manner. In general, the decision to use higher-frequency data (for example, weekly observations rather than monthly observations) means shorter samples (see Table 2). High-frequency data also tend to be more volatile and may yield false signals. ${ }^{4}$

In an attempt to mitigate the problems associated with the lack of ideal data, the number of variables used to construct an FSI or FCI ranges from 5 (MAFCI) to 100 (NFCI). Indexes with more variables (e.g., the NFCI; Hatzius et al., 2010), however, tend to classify themselves as FCIs and tend to contain a larger number of additional price and consumer finance variables. Further, indexes with more variables tend to incorporate data observed at multiple frequencies or multiple principal components (PCs), in addition to taking advantage of an unbalanced panel

(Hatzius et al., 2010). $\underline{5}$

Different researchers choose data that they believe reflect important aspects of the financial market to construct measures of financial stress. Although the categories are somewhat subjectively chosen, these include economic fundamentals, yields, interest rate spreads that measure risk premiums, interest rate spreads that measure the term premium, interest rate spreads that measure the liquidity premium, stock market indicators, volatility indicators, foreign exchange indicators, spreads with consumer lending rates, and quantities.

Table 2 also contains a (noncomprehensive) list of the indicators that fall into each of these categories. The overlap across the various stress indexes is substantial, as expected. The economic fundamentals include the federal funds rate and interest rate spreads, such as the 1-year 1-month LIBOR spread and the 10-year nominal Treasury - 10-year Treasury Inflation-Protected Securities (TIPS) yield spread. These variables are intended to capture inflation expectations and uncertainty due to monetary policy. Other yields are added to examine individual financial variables, such as yields on Treasury securities and commercial paper rates of various maturities.

Credit spreads, which are a measure of risk premiums, are another popular indicator. For example, the interest rate spread between two different types of financial instruments with the same term length is viewed as a measure of investors' appetite for risk relative to the variation in instrument quality. Generally, the spreads in this category are those between yields on investment- or non-investment-grade corporate bonds and Treasury securities. A rise in this spread might also be viewed as an increase in default risk associated with certain bonds, such as "junk bonds." This spread could also change if financial turmoil in global markets leads to a flight to quality, which tends to lower yields on Treasury securities. This phenomenon occurred in 2011 and 2012 during the European sovereign debt crisis. Another type of risk premium measures the yield spread between the same financial instruments but with different term lengths. This type of spread is known as a term premium. The best-known term premium is the difference between the yield on 3-month Treasury securities and 10- or 30-year Treasury securities.

Another type of risk is liquidity risk. Liquidity risk captures the relative ease (or difficulty) of converting financial assets into cash or its equivalent. One popular type of liquidity premium uses on-the-run and off-the-run Treasury spreads, the Treasury bill - eurodollar (TED) spread, and/or the LIBOR - Overnight Indexed Swap (OIS) spread. $\underline{6}$ The liquidity premium data indicate perceived credit risk and, thus, perceived risk of interbank loan defaults. In addition to using government-backed securities, many FSIs consider equity markets by incorporating composite 


\section{Kliesen, Owyang, Vermann}

equity prices measures, such as the financial beta, the financial market cap, bank stock returns, and indexes of investment grades. These variables generally reflect expectations surrounding company profitability and overall market profitability.

Similarly, the set of market volatility indicators helps FSIs capture investor uncertainty. The Chicago Board Options Exchange Market Volatility Index (VIX), the idiosyncratic volatility (IVOL) of bank stock prices, Merrill Lynch Option Volatility Expectations, Merill Lynch Swaption Volatility Expectations, and 3-month Treasury bill bid-ask spread measure the contribution of investor uncertainty to financial stress. ${ }^{-}$

A few FSIs also use foreign exchange measures that evaluate the strength of the U.S. dollar use measures of (i) a broad trade-weighted real exchange rate, (ii) time-varying exchange rate volatility, (iii) U.S.-U.K. covered interest rate differentials, or (iv) real exchange rate growth. These indicators help measure the interconnectedness of international financial markets and the overall strength of the U.S. (or home) economy relative to the global economy. Flight-toquality effects during global financial turmoil also tend to be reflected in exchange rates.

The final two types of indicators - consumer interest rate spreads and quantities-are usually found only in FCIs. The consumer rate spreads take into account interest rate spreads on mortgages, car loans, personal loans, mortgage-backed securities, and asset-backed securities, as well as perceptions of credit conditions from consumer surveys. The quantity index takes into account stock quantities of loans, commercial paper issuance, and debt outstanding.

From this large list of indicators, the most often used variable categories are quality, term, and liquidity premium indicators: Every article studied here uses at least one of the variables in each of those categories. Overall, the most frequently used variable is the TED spread, which is used in eight indexes: Cardarelli, Elekdag, and Lall (2011); Hatzius et al. (2010); the Kansas City Fed's FSI (KCFSI, Hakkio and Keeton, 2009); Bloomberg FCI (BFCI; Rosenberg, 2009); CFSI; CLNFCI; STLFSI; and NFCI. The second most-used indicator is the VIX, which is used in six indexes: Nelson and Perli (2007), KCFSI, CLNFCI, STLFSI, NFCI, and BFCI. The third mostused indicator is the 10-year Treasury - 3-month Treasury spread, which is used in four of the indexes: Hatzius et al. (2011), KCFSI, CFSI, and STLFSI.

Table 2 also shows that, within the same index, a single FSI may use a number of variables from the same data category. This redundancy provides a more detailed picture of an extremely complex financial market. On the other hand, adding more redundant indicators may not improve the index (Lo Duca and Peltonen, 2011). Furthermore, according to Grimaldi (2010, 2011), too many variables could lead to more false "high stress episodes." In other words, too many similar variables may oversignal/overestimate the level of financial stress by overweighting a particular aspect of financial stress.

\section{Data Aggregation}

Once the data for an FSI are collected, they must be aggregated into one measure. Economists often summarize the information in several series with a single index (e.g., the indexes of coincident, leading, and lagging indicators). Indexes may better capture the co-movement of a broad array of economically important series across the business cycle or they may simply be easier to digest.

In order to construct the FSIs and FCIs, the data are generally converted to a common unit. The most common conversion is standardizing each variable; this is usually done by subtract- 
ing its historical (sample) mean and dividing by its standard deviation (Nelson \& Perli, 2007; Cardarelli, Elekdag, and Lall, 2011; CLNFCI; STLFSI; KCFSI). With this approach, fluctuations across variables are on the same scale. Other methods of standardization include studying the difference in a variable's level relative to an average from a reference period (the Goldman Sachs Financial Conditions Index [GSFCI], Dudley and Hatzius, 2000) or standardizing based on each indicator's cumulative density function (CDF; CFSI). More complicated methods include passing data through various filters (NFCI) or eliminating variability that can be explained by historical real activity of inflation (Hatzius et al., 2010).

In the process of constructing the indexes, data may also be grouped into subindexes. Grouping the data in this manner highlights the fluctuations in similar variables and is especially useful when multiple variables from the same subcategory are used. Four of the 11 U.S. FSIs we examined group the data into thematic subindexes and aggregate them within these subindexes. Two of these 4 indexes - the BFCI and Cardarelli, Elekdag, and Lall (2011) - aggregate the factors in each subindex using equal weighting.

The CLNFCI and Nelson and Perli (2007), on the other hand, use a different method. They create subindexes that measure 3 different traits (level, volatility, and co-movement) of 12 variables. The level subindex standardizes the variables based on their long-run averages, and the volatility subindex equally weights the sums of the squared 8 -week rolling window changes in the data. In the CLNFCI, the comovement subindex uses PCs for a 26-week window. The comovement subindex in Nelson and Perli (2007) tracks the percentage of total variation of the individual variables that is defined by a single common factor.

The simplest method of aggregating indicators (or subindexes) into a final index is equal weighting (Cardarelli, Elekdag, and Lall, 2011, and BFCI). In this method, the indicators (subindexes) are averaged together to produce a final measure.

More complicated aggregation methods include regression-based, PCs, or credit-based weighting. Regression-based weights can be constructed by regressing the financial indicators on a measure of output growth (GSFCI). In following this method, additional meaning can be attributed to a rise in financial stress since a change in the level of each indicator directly correlates with a change in GDP growth. Regression-based weights can also be constructed using a logistic regression of known periods of financial stress (Nelson and Perli, 2007, and CLNFCI).

The indexes that do not use a regression-based method (Hatzius et al., 2010; STLFSI; KCFSI; NFCI) determine weights using PC analysis (PCA). .8 In layman's terms, PCA assumes that each of the variables used to construct the FSI (see Table 1) captures some aspect of financial stress. As a result, as the level of financial stress in the economy changes, the variables used to construct the FSI are likely to move together. In the case of the STLFSI, it is assumed that financial stress is the most important factor in explaining the comovement of the 18 variables used to construct the index. This factor, which is the first PC, becomes the FSI. PCA is a relatively inexpensive method of extracting a common component among many variables.

The CFSI uses credit weights for its final stress measure. Rather than using weights determined by PCA, Oet et al. (2011) calculate weights using data from the Federal Reserve Board's flow of funds statistical release. In their methodology, the flow of funds data are separated into four sectors: bank loans, foreign exchange credit, equity, and debt. Then they calculate a 


\section{Figure 2}

\section{U.S. Financial Stress Indexes}
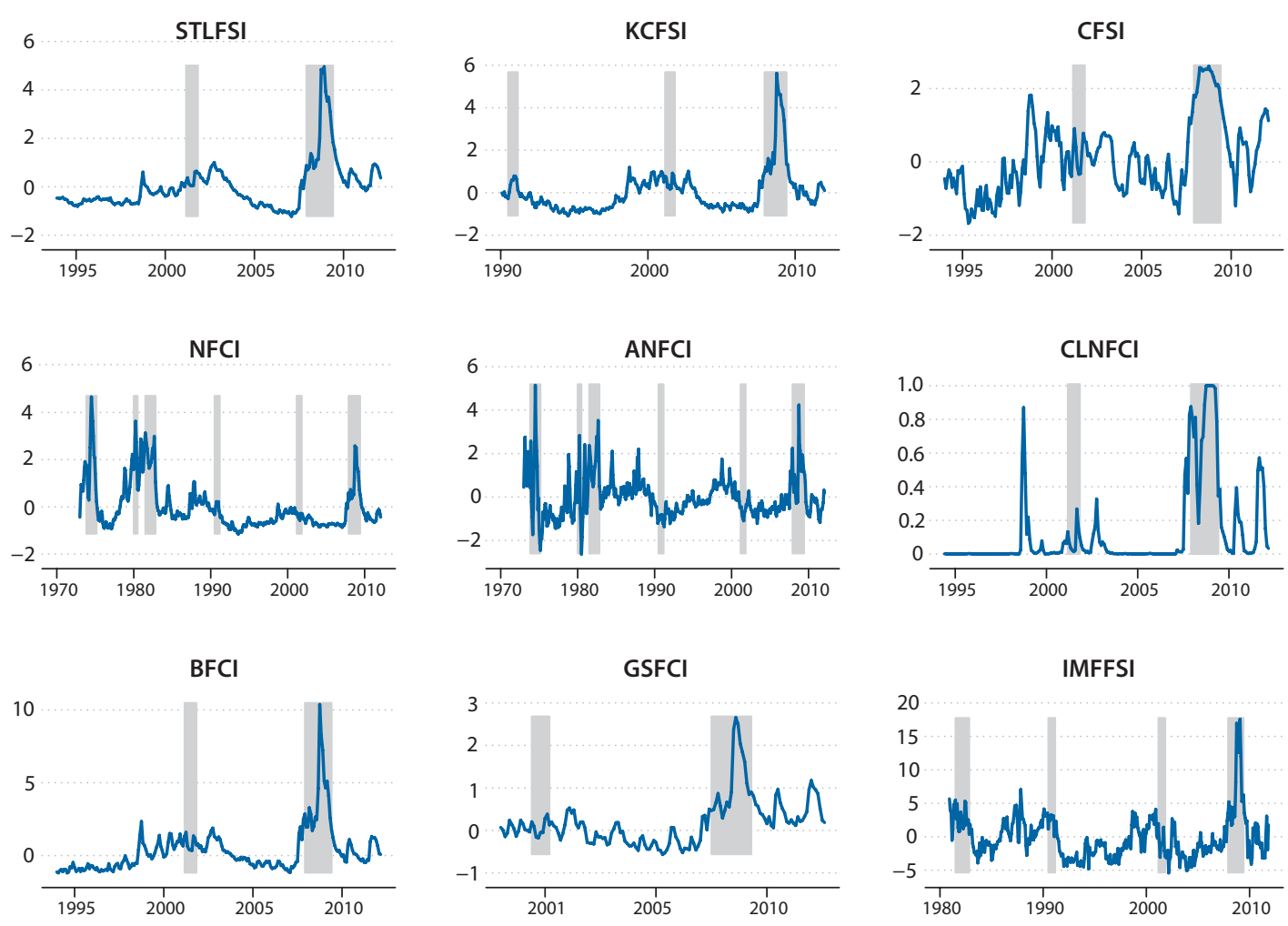

NOTE: Shaded areas denote recessions as defined by the National Bureau of Economic Research.

$z$-proportion of the flow of funds through each of those sectors. After classifying their indicators into those sectors, Oet et al. average the $z$-proportion across the number of indicators in the sector. 9

Figure 2 shows several FSIs for the United States. The shaded bars denote recessions as determined by the National Bureau of Economic Research (NBER) Business Cycle Dating Committee. FSIs do not appear to be (negatively) correlated with the business cycle. For example, the correlation between the STLFSI and the business cycle is 0.64 .

Given the many weighting and aggregating schemes, does any particular method outperform the rest? Oet et al. (2011) and Illing and Liu (2006) compare alternative weighting schemes. Illing and Liu (2006) find that credit weights based on the sum of bank credit, corporate bonds, government bonds, equities, and U.S. dollar credit minimize errors attributable to rank ordering, minimize root mean squared errors (RMSEs), and Granger-cause financial stress crises. Oet et al. (2011) also find that credit weights based on the flow of funds are optimal if the FSI is intended to be an early warning sign of a crisis. They compared the number of stress episodes detected by candidate FSI series (credit weights, PC weights, equal variance weights, and equal weights) with the number detected by benchmark volatility measures (VIX, Merrill Lynch 
Option Volatility Estimate Index, the implied volatility of the Deutscher Aktien Index, Lehman Brothers Swaptions Volatility Index, and Barclays Swaptions Volatility index).

\section{FSIs FROM AROUND THE WORLD}

How do the financial stress measures using U.S. data compare with those using international data? In this section, we discuss the general trends in variables and construction of FSIs from Greece (Louzis and Vouldis, 2011), Sweden (Sandhal et al., 2011), Canada (Illing and Liu, 2006), Denmark (Hansen, 2006), Switzerland (Hanschel and Monnin, 2005), Colombia (Morales and Estrada, 2010), and Hong Kong (Yiu, Ho, and Lin, 2010). We also discuss indexes that use data from multiple countries such as the euro area (Grimaldi, 2010, 2011; Hollo, Kremer, and Lo Duca, 2012); the International Monetary Fund (IMF, Cardarelli, Elekdag, and Lall, 2011; Danninger et al., 2009); and Lo Duca and Peltonen (2011).

\section{Data}

Of the international FSIs we examined (Table 3), the types of data used show considerable overlap with those used in U.S. measures of financial stress, reflecting the global nature of financial markets. The international FSIs all use data that assess the quality premium, term premium, liquidity premium, equity market, market volatility, and foreign exchange market. To do so, these indexes include bond quality spreads (i.e., AA corporate bond - government bond spreads), interbank rate spreads, stock price indexes, and volatility indexes. However, Morales and Estrada (2010) and Hanschel and Monnin (2005) almost exclusively use bank-specific data.

\section{Aggregation of Index Components}

Unlike the U.S. financial stress measures, most of the international FSIs we studied first aggregate their components into thematic subindexes and then aggregate those subindexes into the final composite financial stress measure. This strategy is used by the IMF (Danninger et al., 2009); Greece (Louzis and Vouldis, 2011); Hong Kong (Yiu, Ho, and Jin, 2010); Grimaldi (2010, 2011); and Hollo, Kremer, and Lo Duca (2011). With the exception of Grimaldi (2010, 2011), who creates subindexes based on Nelson and Perli (2007), these measures contain thematic subindexes. To aggregate the factors in the subindexes, authors use PCs (Louzis and Vouldis, 2011), equal weights (Danninger et al., 2009; Yiu, Ho, and Jin, 2010), and CDFs (Hollo, Kremer, and Lo Duca, 2011).

To aggregate indicators (or subindexes), authors use equal weights (Danninger et al., 2009; Lo Duca and Peltonen, 2011; Hansen, 2006; Sandhal et al., 2011; Yiu, Ho, and Jin, 2010; Hanschel and Monnin, 2005), credit weights (Illing and Liu, 2006), or regression-based methods (Grimaldi, 2010, 2011; Louzis and Vouldis, 2011; Hollo, Kremer, and Lo Duca, 2011). The most novel method - the portfolio-theory-based method used by Hollo, Kremer, and Lo Duca (2011) and Louzis and Vouldis (2011) - involves weights based on the number of markets in which financial stress is prevalent. In other words, the weights are dynamic and based on what the data show in each given situation. This method limits the likelihood of false stress incidents.

Figure 3 shows a few of the FSIs created for various countries. Visual inspection suggests a high correlation across countries consistent with the notion that financial stress spreads faster

across borders than other economic shocks. 


\section{Kliesen, Owyang, Vermann}

\section{Table 3}

\section{International Financial Stress Data}

\begin{tabular}{|c|c|c|c|c|c|c|c|c|c|c|c|}
\hline & \multicolumn{11}{|c|}{ Indexes } \\
\hline Indicator & $\stackrel{\bar{n}}{\stackrel{\bar{\nu}}{\Sigma}}$ & 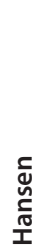 & 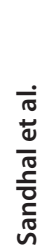 & $\stackrel{ગ}{\rangle}$ & 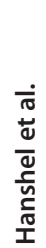 & $\begin{array}{l}\frac{n}{0} \\
0 \\
0 \\
\infty \\
\frac{n}{N} \\
0 \\
0\end{array}$ & 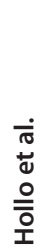 & 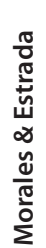 & 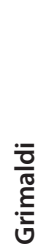 & 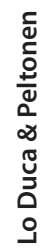 & 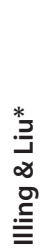 \\
\hline
\end{tabular}

Fundamentals

Bank intermediation spread

Banking distress indicator

Monetary financial institutions emergency lending

at central bank

\section{Foreign exchange}

Exchange rate volatility

$x$

$\mathrm{x} \quad \mathrm{x}$

$x$

$x$

Covered Canada - U.S. 90-day Treasury spread

\section{Quality}

A financial - Nonfinancial bond spread

AA-rated corporate debt - JP Morgan Emerging Markets bond index spread

AA risk spread

AAA - Government bond spread

Banks' stock price idiosyncratic risk

BBB-rated - AAA corporate bond debt spread

$\mathrm{BBB}$ risk spread

BBB - High-yield bond spread as a percentage of

German bond spread

Commercial paper rate - Government rate spread

Corporate bond yield spread

Corporate bond yield spread

Equity risk premium

Excess return of government bonds over equity index

Government-issued debt - JP Morgan Emerging

Markets Bond Index spread

High-yield risk spread

Sovereign government - External low-risk government debt spread

Bank bond yield spread

\section{Equity}

Stock market returns

Bank stock price index

Stock \& bond correlation

Stock market prices

Earnings per share

Financial stock prices $x$

x x

x

$x$

$\mathrm{X}$ $\mathrm{x}$

X

X

\section{$\mathrm{X}$}

$x$

$\mathrm{X}$ $x$ 


\section{Table 3, cont'd}

\section{International Financial Stress Data}

\begin{tabular}{|c|c|c|c|c|c|c|c|c|c|c|c|}
\hline \multirow[b]{2}{*}{ Indicator } & \multicolumn{11}{|c|}{ Indexes } \\
\hline & $\stackrel{\overline{\underline{n}}}{\underline{\underline{L}}}$ & 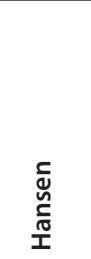 & 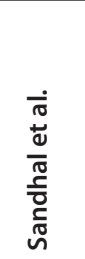 & $\stackrel{\supset}{\supset}$ & 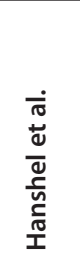 & $\begin{array}{l}\frac{n}{0} \\
0 \\
0 \\
\infty \\
0 \\
: \frac{n}{N} \\
0\end{array}$ & 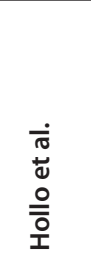 & 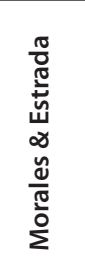 & $\begin{array}{l}\stackrel{\overline{0}}{\frac{0}{\pi}} \\
\stackrel{\text { है }}{\frac{5}{5}}\end{array}$ & 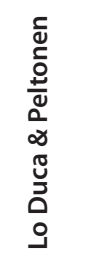 & 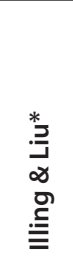 \\
\hline Inverse price-to-book ratio & & & & & & & $x$ & & & & \\
\hline Banking sector beta & $x$ & & & & & & & & & & $x$ \\
\hline \multicolumn{12}{|l|}{ Term } \\
\hline Inverted term spread & $x$ & & & $x$ & & & & & & & \\
\hline \multicolumn{12}{|l|}{ Liquidity } \\
\hline Interbank (TED) spread & $x$ & & $x$ & $x$ & & $x$ & $x$ & & $x$ & $x$ & \\
\hline $\begin{array}{l}\text { 10-year euroswap - 10-year German government } \\
\text { bond spread }\end{array}$ & & $\mathrm{x}$ & & & & & & & & & \\
\hline 10-year interest rate swap spread & & & & & & & $x$ & & & & \\
\hline Government bond bid-ask spread & & & & & & & & & & & $\mathrm{x}$ \\
\hline \multicolumn{12}{|l|}{ Volatility } \\
\hline Stock market volatility & $x$ & $x$ & $x$ & $x$ & & $x$ & $x$ & & $x$ & $x$ & \\
\hline 1-year swap - 1-year-ahead implicit volatility & & $\mathrm{x}$ & & & & & & & $\mathrm{x}$ & & \\
\hline 10-year swap - 1-year-ahead implicit volatility & & $x$ & & & & & & & $x$ & & \\
\hline Banking index realized volatility & & & & & & $x$ & & & & & \\
\hline Euro Interbank Offered Rate volatility & & & & & & & $\mathrm{x}$ & & & & \\
\hline Government bond volatility & & & & & & $\mathrm{x}$ & $\mathrm{x}$ & & & $x$ & \\
\hline \multicolumn{12}{|l|}{ Excess equity return realized volatility } \\
\hline Long implied bond volatility & & & & & & & $x$ & & $\mathrm{x}$ & & $\mathrm{x}$ \\
\hline \multicolumn{12}{|l|}{ Yield } \\
\hline Inverted yield curve & & & & & & & & & & & $x$ \\
\hline \multicolumn{12}{|l|}{ Consumer } \\
\hline Perceptions of banking conditions & & & & & $x$ & & & & & & \\
\hline Return on banking sector assets & & & & & $x$ & & & $x$ & & & \\
\hline Refinancing rate - 2-year bond spread & & & & & & & & & $x$ & & \\
\hline Covered bonds - government bond spread & & & $x$ & & & & & & & & \\
\hline \multicolumn{12}{|l|}{ Quantity } \\
\hline Bank balance sheet data & & & & & $x$ & $x$ & & $x$ & & & \\
\hline Total interbank deposits & & & & & $x$ & & & & & & \\
\hline Variation in bank capital & & & & & $\mathrm{x}$ & & & & & & \\
\hline Number of bank branches & & & & & $x$ & & & & & & \\
\hline \multicolumn{12}{|l|}{ Other information } \\
\hline Number of indicators & 7 & 8 & 4 & 7 & 8 & 14 & 15 & 9 & 16 & 5 & 7 \\
\hline Start year & 1980 & 1999 & 1997 & 1997 & 1991 & 2001 & 1987 & 1995 & 1999 & 1990 & 1981 \\
\hline Frequency & M & $\mathrm{Q}$ & $M$ & $M$ & $M$ & $M$ & W & $M$ & $\mathrm{D}$ & $\mathrm{Q}$ & $M$ \\
\hline
\end{tabular}




\section{Figure 3}

\section{International Financial Indexes}
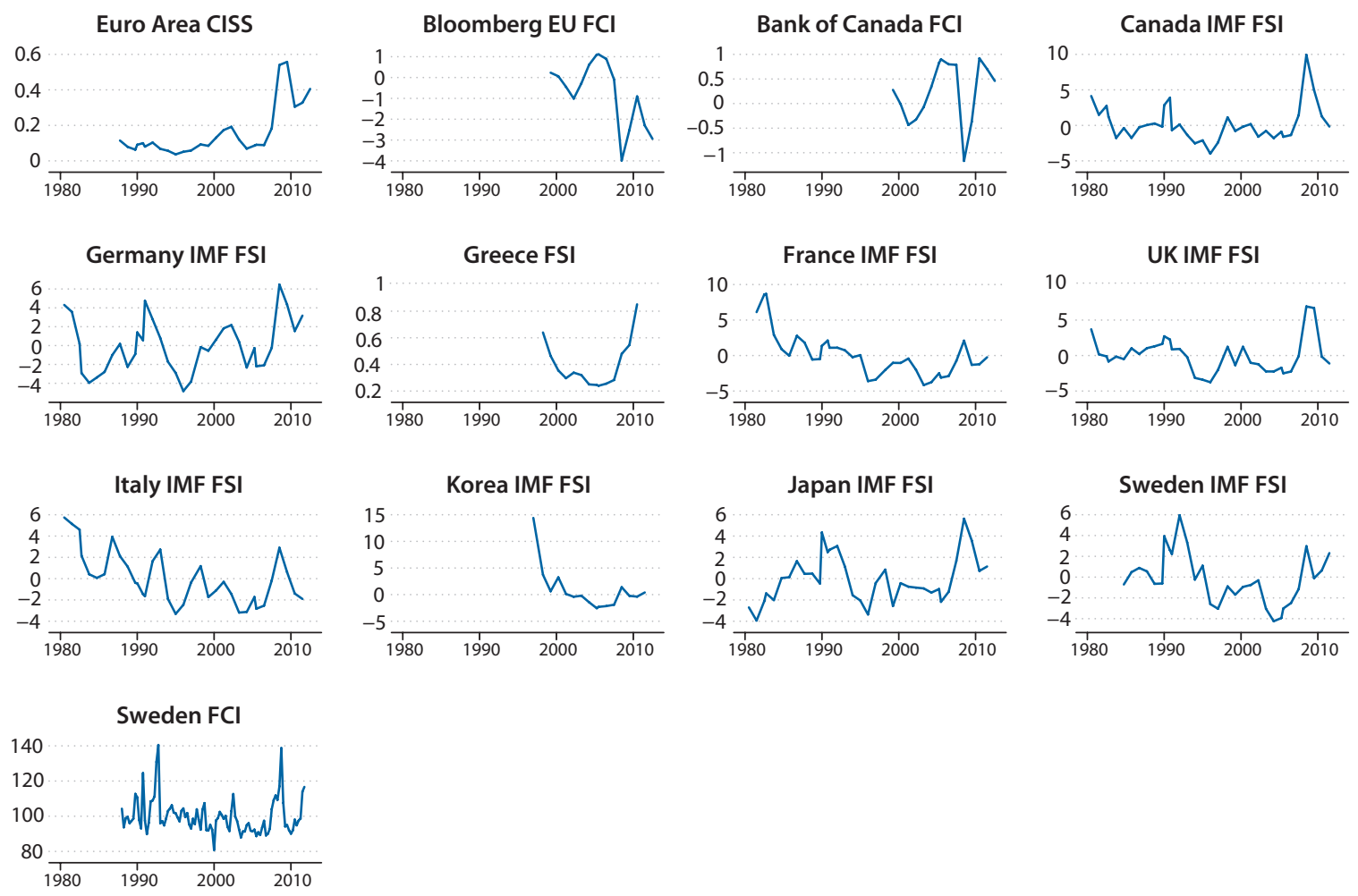

\section{EMPIRICAL ANALYSIS}

In general, the usefulness of an indicator lies in its ability to measure what it was designed to measure. By and large, FSIs are designed to measure increases in financial instability, as depicted in measures such as rising risk premiums, falling asset prices, or increased volatility. Rising levels of financial stress (instability) tend to increase uncertainty and weaken the real economy by a variety of transmission mechanisms. These include reduced wealth, a reduction in bank lending, and balance sheet effects that reduce the value of a firm's collateral. Figure 4 depicts this inverse relationship between financial stress and economic activity by plotting the monthly average of the STLFSI and the year-to-year growth of industrial production. The relatively high $R$-squared value (0.52) indicates that, consistent with our prior belief, relatively high levels of financial stress are associated with weak or negative growth of industrial production.

But does such a relationship exist with other measures of financial stress and other measures of economic activity? We consider this question in the remainder of this section in two ways. First, we compute the correlations among the measures of U.S. financial stress: the CFSI, the BFCI, the CLNFCI, the GSFSI, the NFCI, the Chicago Fed's Adjusted NFCI (ANFCI; Brave and Butters, 2011), the STLFSI, the KCFSI, and the IMF's Advanced Economies FSI for the U.S. 


\section{Figure 4}

\section{Inverse Relationship between Financial Stress and Economic Activity}

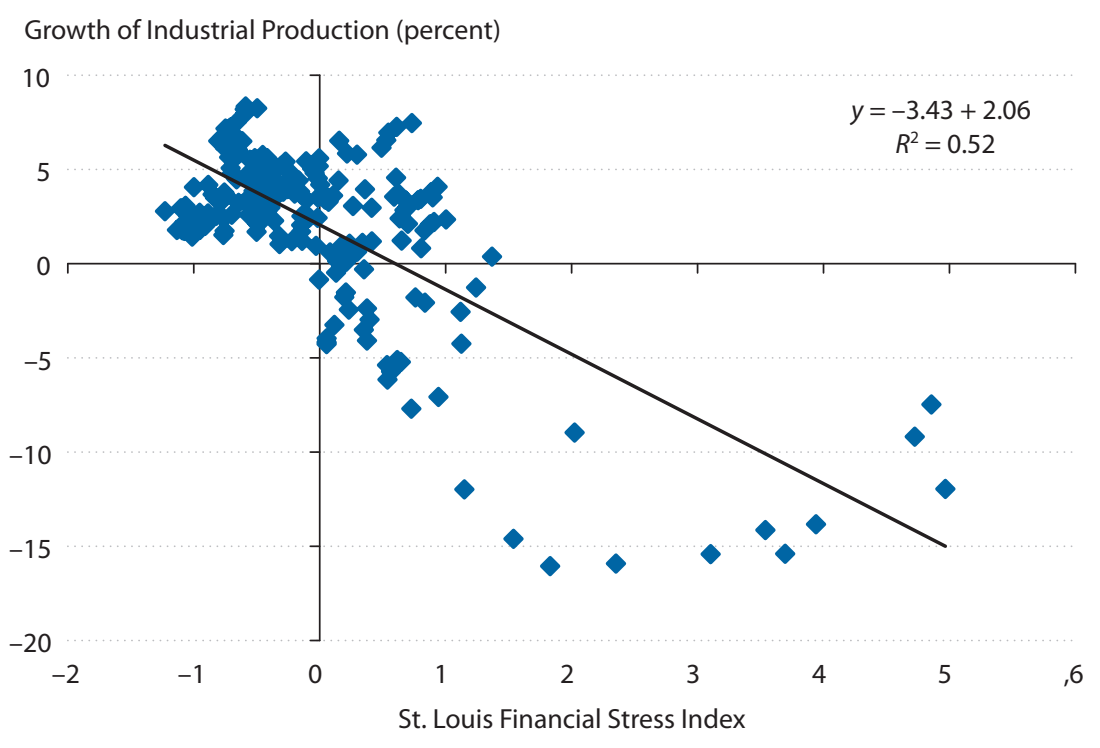

(IMFFSI). $\underline{10}$ Then we perform some simple forecasting experiments designed to determine whether the stress indexes predict growth.

\section{Correlations}

Although various researchers' definitions of financial stress differ, the indexes are, for the most part, intended to measure the same thing: the degree of financial instability reflected in economic and financial market variables. Thus, we expect to find that various FSIs are highly, but not exactly, correlated. Tables 4, 5, and 6 indicate that FSIs are no more correlated with each other than with FCIs. Regardless, if shocks hitting the financial markets are also propagated to the macroeconomy, then FSIs and FCIs would also be expected to have a high degree of correlation. Tables 4 through 6 show the correlations among the different indexes in the United States at various frequencies. Higher-frequency indexes are matched with lower-frequency ones by simple averaging.

Our hypothesis that the various indexes would not be exactly correlated is verified; this occurs because the different indexes, while intended to measure stress in general, emphasize different components of financial markets. Still, the overlap in the input data is substantial and makes the indexes highly correlated (typically over 0.7 ). Table 5 also indicates that the ANFCI tends to have the smallest correlation with the other eight indexes.

The correlations in Tables 4 through 6 are computed over the entire time sample. The FSIs, however, are designed to indicate when financial market instability is high. Thus, high correlation when markets are performing well may be misleading. On the other hand, low correlation during these same "safe" periods may not be troublesome if the FSIs do move together in times of stress. 
Kliesen, Owyang, Vermann

Table 4

Correlation of Daily Frequency Financial Indexes

\begin{tabular}{|c|c|c|c|c|}
\hline & CLNFCI & $\mathrm{BFCl}$ & CFSI & GSFCI \\
\hline CLNFCI & 1 & & & \\
\hline $\mathrm{BFCl}$ & 0.84 & 1 & & \\
\hline CFSI & 0.73 & 0.79 & 1 & \\
\hline GSFCI & 0.82 & 0.86 & 0.75 & 1 \\
\hline
\end{tabular}

\section{Table 5}

\section{Weekly Correlations}

\begin{tabular}{|c|c|c|c|c|c|c|c|}
\hline & NFCl & ANFCI & STLFSI & CFSI & BFCl & GSFCI & CLNFCI \\
\hline $\mathrm{NFCl}$ & 1 & & & & & & \\
\hline ANFCI & 0.64 & 1 & & & & & \\
\hline STLFSI & 0.90 & 0.52 & 1 & & & & \\
\hline CFSI & 0.79 & 0.48 & 0.75 & 1 & & & \\
\hline $\mathrm{BFCl}$ & 0.94 & 0.63 & 0.92 & 0.79 & 1 & & \\
\hline GSFCI & 0.88 & 0.64 & 0.92 & 0.76 & 0.86 & 1 & \\
\hline CLNFCI & 0.86 & 0.62 & 0.81 & 0.74 & 0.84 & 0.82 & 1 \\
\hline
\end{tabular}

NOTE: Correlations are calculated for the overlapping samples of each index.

\section{Table 6}

\section{Monthly Correlations}

\begin{tabular}{|c|c|c|c|c|c|c|c|c|c|}
\hline & IMFFSI & KCFSI & $\mathrm{NFCl}$ & ANFCI & STLFSI & CLNFCI & BFCI & CFSI & GSFCI \\
\hline IMFFSI & 1 & & & & & & & & \\
\hline KCFSI & 0.86 & 1 & & & & & & & \\
\hline $\mathrm{NFCl}$ & 0.68 & 0.95 & 1 & & & & & & \\
\hline ANFCI & 0.58 & 0.60 & 0.65 & 1 & & & & & \\
\hline STLFSI & 0.78 & 0.92 & 0.90 & 0.52 & 1 & & & & \\
\hline CLNFCI & 0.78 & 0.82 & 0.87 & 0.64 & 0.82 & 1 & & & \\
\hline $\mathrm{BFCl}$ & 0.83 & 0.96 & 0.95 & 0.63 & 0.92 & 0.85 & 1 & & \\
\hline CFSI & 0.69 & 0.80 & 0.79 & 0.51 & 0.76 & 0.76 & 0.80 & 1 & \\
\hline GSFCI & 0.81 & 0.87 & 0.88 & 0.66 & 0.92 & 0.83 & 0.87 & 0.77 & 1 \\
\hline
\end{tabular}




\section{Figure 5}

\section{Two-Year Rolling Correlation of St. Louis Fed and Kansas City Fed FSIs}

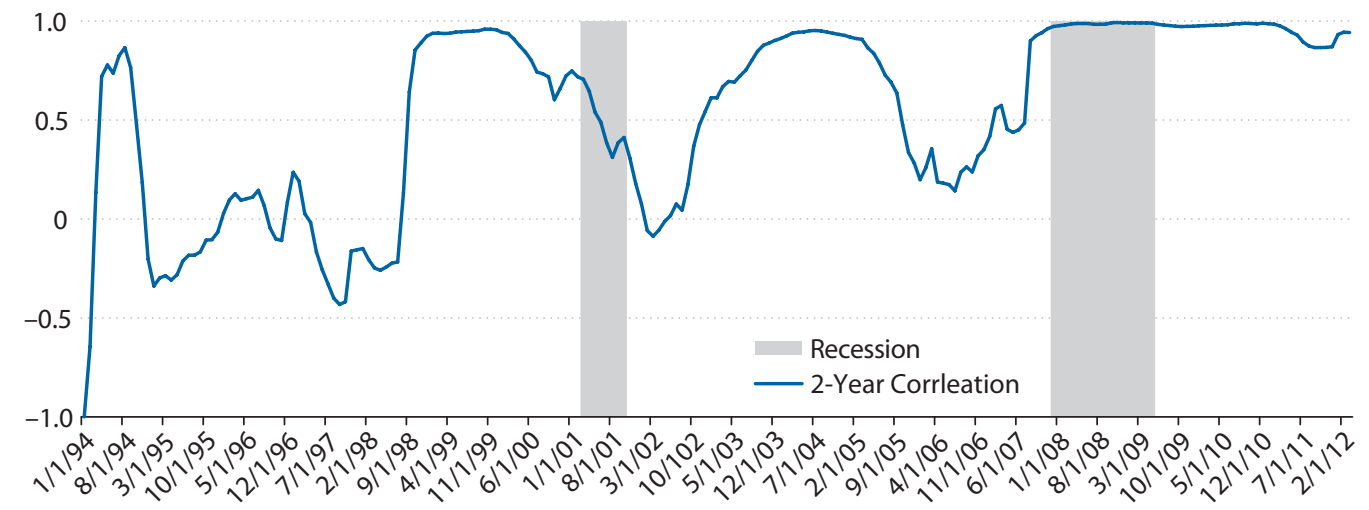

NOTE: Shaded areas denote recessions as defined by the National Bureau of Economic Research.

To assess whether there is some time variation in the correlations, we compute a rolling 2-year centered correlation for two of the FSIs: the STLFSI and the KCFSI. Figure 5 shows a nearly perfect correlation during the Great Recession and recovery, as well as in a period of financial stability in the late 1990s/early 2000s. Interestingly, correlations between the two series were different in the earlier period. Before the 2001 recession, which was relatively shallow and short, the correlation between the two FSIs was initially high but then declined prior to and during the recession. An opposite pattern occurred prior to and during the 2007-09 period. Since the two recessions were very different in magnitude and duration and the principal causes arose from different shocks, it might seem reasonable to conclude that FSIs differ in their ability to discern shocks across business cycles, particularly if these shocks are heterogeneous. Admittedly, data limitations prevent rigorous testing of this hypothesis. Still, Figure 5 suggests some indexes may perform better than others in predicting economic downturns, particularly if the shocks are idiosyncratic. Presumably, though, all of the FSIs and FCIs would do well in predicting economic downturns arising from systemic shocks, such as the 2007-09 recession.

Stress may also propagate through international financial markets faster than economic shocks; thus, a high level of correlation in the FSIs across countries might be expected. Table 7 shows the correlations for some of the indexes around the world and two U.S. indexes. For example, the correlations between the STLFSI and international indexes over the sample periods for which the series overlap range from 0.23 (Korea) to 0.91 (Bloomberg EU); the average is 0.66 . The other U.S. index in Table 7 is the IMFFSI. Its correlation ranges from 0.40 (Korea) to 0.78 (STLFSI); the average is 0.65 . Thus, while the correlation between these two U.S. FSIs and the international indexes is relatively high, the cross-country correlations in Table 7 are generally lower on average than the U.S.-only correlations in Table 6. This suggests that, once again, not all shocks are propagated fully across international financial markets. 
Kliesen, Owyang, Vermann

Table 7

U.S. and International Correlations (Monthly Series)

\begin{tabular}{|c|c|c|c|c|c|c|c|c|c|c|c|c|}
\hline & $\begin{array}{l}\text { U.S. } \\
\text { IMFFSI }\end{array}$ & STLFSI & $\begin{array}{l}\text { Euro } \\
\text { CISS }\end{array}$ & $\begin{array}{c}\text { Greece } \\
\text { FSI }\end{array}$ & $\begin{array}{l}\text { Bank of } \\
\text { Canada }\end{array}$ & $\begin{array}{l}\text { oomberg } \\
\text { EU }\end{array}$ & $\begin{array}{c}\text { Germany } \\
\text { IMF }\end{array}$ & $\begin{array}{l}\text { France } \\
\text { IMF }\end{array}$ & $\begin{array}{l}\text { U.K. } \\
\text { IMF }\end{array}$ & $\begin{array}{l}\text { Italy } \\
\text { IMF }\end{array}$ & $\begin{array}{l}\text { Korea } \\
\text { IMF }\end{array}$ & $\begin{array}{c}\text { Japan } \\
\text { IMF }\end{array}$ \\
\hline U.S. IMFFSI & 1 & & & & & & & & & & & \\
\hline STLFSI & 0.78 & 1 & & & & & & & & & & \\
\hline Euro CISS & 0.64 & 0.89 & 1 & & & & & & & & & \\
\hline Greece FSI & 0.47 & 0.50 & 0.51 & 1 & & & & & & & & \\
\hline Bank of Canada & 0.72 & 0.78 & 0.51 & 0.22 & 1 & & & & & & & \\
\hline Bloomberg EU & 0.75 & 0.91 & 0.89 & 0.56 & 0.66 & 1 & & & & & & \\
\hline Germany IMF & 0.58 & 0.77 & 0.66 & 0.40 & 0.65 & 0.81 & 1 & & & & & \\
\hline France IMF & 0.46 & 0.44 & 0.27 & 0.29 & 0.45 & 0.59 & 0.31 & 1 & & & & \\
\hline U.K. IMF & 0.77 & 0.82 & 0.69 & 0.49 & 0.72 & 0.80 & 0.64 & 0.34 & 1 & & & \\
\hline Italy IMF & 0.46 & 0.56 & 0.34 & 0.39 & 0.58 & 0.65 & 0.32 & 0.61 & 0.48 & 1 & & \\
\hline Korea IMF & 0.40 & 0.23 & 0.12 & 0.40 & 0.45 & 0.43 & 0.30 & 0.26 & 0.36 & 0.43 & 1 & \\
\hline Japan IMF & 0.51 & 0.72 & 0.56 & 0.44 & 0.63 & 0.76 & 0.53 & 0.17 & 0.70 & 0.26 & 0.29 & 1 \\
\hline
\end{tabular}

NOTE: Correlations are calculated for the overlapping samples of each index. CISS, Composite Indicator of Systemic Stress; EU, European Union.

\section{Forecasting Experiments}

Our next objective is to determine whether the various FSIs predict economic growth. To do this, we conduct a series of simple pseudo out-of-sample forecasting experiments. $\frac{11}{1}$ The forecasting model is a simple bivariate vector autoregression of the form

$$
Y_{t}=C+A(L) * Y_{t-1}+\varepsilon_{t}
$$

where $Y_{t}$ is a vector consisting of the period- $t$ values of an economic indicator (say, industrial production) and an FSI, $A(L)$ is a matrix polynomial in the lag operator, $C$ is a constant, and $\varepsilon_{t}$ is the period- $t$ reduced-form residual assumed to have a mean of zero and an unknown covariance matrix. We determine the lag order of $A(L)$ using the Bayesian information criterion. Since our forecasting exercises are only illustrative, we choose three macroeconomic indicators and one financial market indicator and generate the forecasts separately. The three nonfinancial indicators are the seasonally adjusted annualized monthly growth rates of industrial production and the seasonally adjusted annualized quarterly growth rate of GDP. The financial indicator is the period-to-period percent change in the Wilshire 5000 stock price index. We use the 2012:03 and 2012:Q1 vintages of data (i.e., not real-time data). The FSIs are aggregated to the monthly and quarterly frequencies by computing the simple monthly average. We consider all horizons up to one year ahead.

The experiments are conducted on a common sample (2000:01-2011:11 or 2000:Q12011:Q3) and full samples for each series (see Appendix A) as follows: First, we split the sample after taking the first 5 years of data, taking this as time $t$. The vector autoregression is estimated using data from the beginning of the sample (Appendix B). 12 Then, we forecast the horizons $t+1$, 
Kliesen, Owyang, Vermann

\section{Table 8}

Relative RMSEs of Monthly Forecast of Industrial Production

\begin{tabular}{|c|c|c|c|c|c|c|c|c|c|}
\hline \multirow[b]{2}{*}{ Months ahead } & \multicolumn{9}{|c|}{ Indexes } \\
\hline & CFSI & $\mathrm{BFCl}$ & CLNFCI & GSFCI & ANFCI & $\mathrm{NFCl}$ & STLFSI & IMFFSI & KCFSI \\
\hline \multicolumn{10}{|l|}{ Common sample } \\
\hline 1 & 1.97 & 1.72 & 1.92 & 1.97 & 1.00 & 1.81 & 1.93 & 1.89 & 1.74 \\
\hline 2 & 2.03 & 1.72 & 1.97 & 2.02 & 1.00 & 1.82 & 1.94 & 1.95 & 1.76 \\
\hline 3 & 2.10 & 1.74 & 2.07 & 2.07 & 1.00 & 1.81 & 1.97 & 1.99 & 1.75 \\
\hline 4 & 2.20 & 1.79 & 2.13 & 2.19 & 1.00 & 1.90 & 2.06 & 2.14 & 1.73 \\
\hline 5 & 2.37 & 1.89 & 2.29 & 2.35 & 1.00 & 2.01 & 2.19 & 2.41 & 1.88 \\
\hline 6 & 2.50 & 1.96 & 2.33 & 2.45 & 1.00 & 2.03 & 2.31 & 2.47 & 1.89 \\
\hline 7 & 2.52 & 1.97 & 2.37 & 2.49 & 1.00 & 2.02 & 2.32 & 2.52 & 1.87 \\
\hline 8 & 2.56 & 2.00 & 2.39 & 2.57 & 1.00 & 2.08 & 2.37 & 2.59 & 1.88 \\
\hline 9 & 2.60 & 2.05 & 2.41 & 2.65 & 1.00 & 2.16 & 2.44 & 2.66 & 1.90 \\
\hline 10 & 2.56 & 2.00 & 2.43 & 2.65 & 1.00 & 2.15 & 2.42 & 2.60 & 1.88 \\
\hline 11 & 2.52 & 1.99 & 2.43 & 2.66 & 1.00 & 2.17 & 2.42 & 2.61 & 1.90 \\
\hline 12 & 2.52 & 1.99 & 2.48 & 2.70 & 1.00 & 2.07 & 2.40 & 2.56 & 1.87 \\
\hline \multicolumn{10}{|l|}{ Full series } \\
\hline 1 & 1.48 & 1.60 & 1.48 & 2.07 & 1.05 & 1.00 & 1.46 & 1.05 & 1.17 \\
\hline 2 & 1.55 & 1.62 & 1.53 & 2.13 & 1.05 & 1.00 & 1.48 & 1.05 & 1.18 \\
\hline 3 & 1.61 & 1.67 & 1.59 & 2.19 & 1.06 & 1.00 & 1.53 & 1.06 & 1.20 \\
\hline 4 & 1.70 & 1.73 & 1.64 & 2.33 & 1.07 & 1.00 & 1.62 & 1.07 & 1.23 \\
\hline 5 & 1.78 & 1.78 & 1.71 & 2.50 & 1.06 & 1.00 & 1.70 & 1.07 & 1.28 \\
\hline 6 & 1.87 & 1.83 & 1.76 & 2.62 & 1.07 & 1.00 & 1.78 & 1.07 & 1.30 \\
\hline 7 & 1.91 & 1.85 & 1.81 & 2.67 & 1.07 & 1.00 & 1.83 & 1.07 & 1.31 \\
\hline 8 & 1.94 & 1.86 & 1.84 & 2.74 & 1.07 & 1.00 & 1.86 & 1.08 & 1.32 \\
\hline 9 & 1.93 & 1.85 & 1.85 & 2.81 & 1.06 & 1.00 & 1.89 & 1.07 & 1.33 \\
\hline 10 & 1.96 & 1.89 & 1.90 & 2.82 & 1.06 & 1.00 & 1.89 & 1.08 & 1.36 \\
\hline 11 & 1.95 & 1.90 & 1.91 & 2.84 & 1.07 & 1.00 & 1.91 & 1.09 & 1.38 \\
\hline 12 & 1.95 & 1.91 & 1.92 & 2.88 & 1.07 & 1.00 & 1.91 & 1.09 & 1.38 \\
\hline
\end{tabular}

$t+2, \ldots, t+12$ for monthly industrial production and the Wilshire 5000 and the horizons $t+1$, $t+2, \ldots, t+4$ for quarterly GDP. Then, we add the next observation of both the economic indicator and the FSI, repeating the estimation and the forecast. Finally, we compute the forecast errors by comparing the forecasts at the different horizons with the realized values.

Tables 8 through 10 present the RMSEs for these forecasting experiments. Rather than reporting the actual RMSEs, we instead report relative forecast errors. In each table, the RMSE of each variable at each forecast horizon is normalized to the lowest RMSE. Thus, an index value of 1.00 indicates that that variable has the smallest forecast error (RMSE) at that particular forecast horizon. All RMSEs at that horizon are then normalized to that RMSE. As an example, in the top panel of Table 8, at the 1-month-ahead forecast horizon, the ANFCI has the smallest RMSE. The BFCI has the next-lowest RMSE (1.72). This means that the RMSE of the BFCI is 72 
Kliesen, Owyang, Vermann

\section{Table 9}

Relative RMSEs of Quarterly Forecast of GDP

\begin{tabular}{|c|c|c|c|c|c|c|c|c|c|}
\hline \multirow[b]{2}{*}{ Months ahead } & \multicolumn{9}{|c|}{ Indexes } \\
\hline & CFSI & $\mathrm{BFCl}$ & CLNFCI & GSFCI & ANFCI & $\mathrm{NFCl}$ & STLFSI & IMFFSI & KCFSI \\
\hline \multicolumn{10}{|l|}{ Common sample } \\
\hline 1 & 1.00 & 1.33 & 1.52 & 1.60 & 2.21 & 1.68 & 1.67 & 1.72 & 1.72 \\
\hline 2 & 1.29 & 1.00 & 2.21 & 1.63 & 3.29 & 1.57 & 1.28 & 2.65 & 1.18 \\
\hline 3 & 1.49 & 1.00 & 2.38 & 1.37 & 3.54 & 1.60 & 1.35 & 2.57 & 1.09 \\
\hline 4 & 1.85 & 1.33 & 2.49 & 1.40 & 3.58 & 1.30 & 1.92 & 2.75 & 1.00 \\
\hline \multicolumn{10}{|l|}{ Full sample } \\
\hline 1 & 1.32 & 1.42 & 1.23 & 1.41 & 1.06 & 1.00 & 1.83 & 1.52 & 1.17 \\
\hline 2 & 1.64 & 1.39 & 1.47 & 1.65 & 1.11 & 1.00 & 1.68 & 1.62 & 1.15 \\
\hline 3 & 1.82 & 1.49 & 1.63 & 1.70 & 1.13 & 1.00 & 1.73 & 1.77 & 1.19 \\
\hline 4 & 1.82 & 1.48 & 1.67 & 1.81 & 1.16 & 1.00 & 1.78 & 1.83 & 1.22 \\
\hline
\end{tabular}

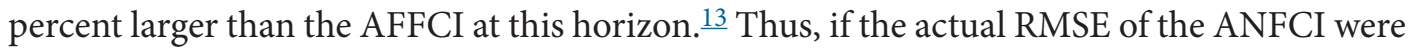
1.5 percent, then the forecast error of the BFCI would be 2.6 percent.

In general, there is little variation in the forecasting ability of the different indexes. As might be expected, the FCIs forecast the macroeconomic indicators better than the FSIs. This could be because the FCIs have a longer sample period than the FSIs and, moreover, have a broader coverage of data designed to predict macro fluctuations, whereas the FSIs are aimed primarily at predicting financial outcomes. Over the common sample, however, the FSIs and FCIs appear to forecast GDP growth equally well. When examining forecasts of changes in the Wilshire 5000, the NFCI, ANFCI, and IMFFSI have the smallest errors (though the NFCI and ANFCI contain the Wilshire 5000) for the full sample. Over the common sample, though, the STLFSI performs well. Regardless of the length of each forecast sample, the FSIs tend to outperform the FCIs in these forecasts.

As a final robustness check, we compute correlations among the FSIs and FCIs in Table 2 with two additional variables (Table 11). The first variable is the Arouba-Diebold-Scotti Business Conditions Index (ADS). The ADS is a mixed-frequency index intended to measure the state of the economy relative to its trend, or steady-state, growth. The second variable is the Senior Loan Officer Opinion Survey (SLOOS) of terms and conditions on commercial and industrial (C\&I) loans at all commercial banks. The SLOOS is intended to measure how shocks affect the willingness of banks to extend C\&I loans. A rise in the SLOOS index thus indicates that banks are tightening the terms and conditions on C\&I loans to firms. The banks' willingness to lend is reflected in the price of the loan (interest rate) and the terms of the loan (for example, maturity and collateral requirements). Both measures are widely used indicators of macroeconomic and financial conditions.

Table 11 indicates that the FSIs and FCIs tend to be highly correlated with the ADS and SLOOS and are of the expected sign. Thus, when an FSI rises, the ADS tends to fall (weaker growth relative to trend) and banks tend to tighten terms and conditions on C\&I loans. The latter is often taken as a sign that banks perceive that emerging macroeconomic and financial 
Table 10

Relative RMSEs of Monthly Forecast of Wilshire $\mathbf{5 0 0 0}$

\begin{tabular}{|c|c|c|c|c|c|c|c|c|c|}
\hline \multirow[b]{2}{*}{ Months ahead } & \multicolumn{9}{|c|}{ Indexes } \\
\hline & CFSI & $\mathrm{BFCl}$ & CLNFCI & GSFCI & ANFCl & $\mathrm{NFCl}$ & STLFSI & IMFFSI & KCFSI \\
\hline \multicolumn{10}{|l|}{ Common sample } \\
\hline 1 & 1.03 & 1.01 & 1.07 & 1.03 & 1.00 & 1.09 & 1.01 & 1.00 & 1.01 \\
\hline 2 & 1.03 & 1.03 & 1.12 & 1.07 & 1.00 & 1.15 & 1.03 & 1.01 & 1.02 \\
\hline 3 & 1.04 & 1.00 & 1.19 & 1.07 & 1.01 & 1.14 & 1.00 & 1.00 & 1.00 \\
\hline 4 & 1.06 & 1.00 & 1.26 & 1.09 & 1.01 & 1.14 & 1.01 & 1.02 & 1.01 \\
\hline 5 & 1.07 & 1.02 & 1.32 & 1.12 & 1.00 & 1.16 & 1.05 & 1.05 & 1.04 \\
\hline 6 & 1.07 & 1.04 & 1.35 & 1.13 & 1.00 & 1.17 & 1.06 & 1.05 & 1.06 \\
\hline 7 & 1.12 & 1.02 & 1.39 & 1.14 & 1.00 & 1.18 & 1.05 & 1.05 & 1.03 \\
\hline 8 & 1.14 & 1.00 & 1.40 & 1.14 & 1.00 & 1.17 & 1.04 & 1.05 & 1.01 \\
\hline 9 & 1.16 & 1.02 & 1.43 & 1.14 & 1.00 & 1.20 & 1.05 & 1.05 & 1.02 \\
\hline 10 & 1.16 & 1.02 & 1.50 & 1.10 & 1.00 & 1.27 & 1.03 & 1.03 & 1.00 \\
\hline 11 & 1.19 & 1.05 & 1.64 & 1.09 & 1.03 & 1.37 & 1.04 & 1.04 & 1.00 \\
\hline 12 & 1.21 & 1.04 & 1.79 & 1.07 & 1.04 & 1.38 & 1.03 & 1.02 & 1.00 \\
\hline \multicolumn{10}{|l|}{ Full sample } \\
\hline 1 & 1.29 & 1.31 & 1.37 & 1.44 & 1.01 & 1.00 & 1.33 & 1.01 & 1.20 \\
\hline 2 & 1.30 & 1.33 & 1.41 & 1.53 & 1.00 & 1.00 & 1.34 & 1.01 & 1.20 \\
\hline 3 & 1.30 & 1.31 & 1.44 & 1.53 & 1.00 & 1.00 & 1.33 & 1.01 & 1.20 \\
\hline 4 & 1.32 & 1.33 & 1.46 & 1.56 & 1.00 & 1.00 & 1.33 & 1.01 & 1.20 \\
\hline 5 & 1.35 & 1.38 & 1.52 & 1.69 & 1.01 & 1.00 & 1.38 & 1.03 & 1.24 \\
\hline 6 & 1.36 & 1.40 & 1.54 & 1.73 & 1.01 & 1.00 & 1.42 & 1.03 & 1.25 \\
\hline 7 & 1.36 & 1.37 & 1.50 & 1.65 & 1.00 & 1.00 & 1.38 & 1.02 & 1.22 \\
\hline 8 & 1.37 & 1.36 & 1.51 & 1.63 & 1.00 & 1.00 & 1.37 & 1.02 & 1.21 \\
\hline 9 & 1.37 & 1.36 & 1.56 & 1.66 & 1.00 & 1.00 & 1.40 & 1.02 & 1.22 \\
\hline 10 & 1.37 & 1.37 & 1.62 & 1.66 & 1.00 & 1.00 & 1.37 & 1.02 & 1.22 \\
\hline 11 & 1.38 & 1.38 & 1.68 & 1.60 & 1.00 & 1.00 & 1.38 & 1.02 & 1.22 \\
\hline 12 & 1.38 & 1.39 & 1.73 & 1.57 & 1.01 & 1.00 & 1.38 & 1.02 & 1.22 \\
\hline
\end{tabular}

conditions may increase the probability of default or delinquency on these loans. Thus, the SLOOS is countercyclical (falling in expansions, rising in recessions). Using the common sample in Table 11, the correlations range from -0.59 (ANFCI) to -0.83 (KCFSI) for the ADS and from 0.56 (ANFCI) to 0.80 (KCFSI). In short, these results support our hypothesis that rising levels of financial stress or weaker financial conditions tend to presage periods of economic and financial weakness.

\section{CONCLUSION}

Financial stress indexes have become an important component of risk management for policymakers and the private sector. Financial stress, though, is unobservable and, thus, difficult 
Kliesen, Owyang, Vermann

Table 11

Correlations with Economic Indicators

\begin{tabular}{|c|c|c|}
\hline Index & $\begin{array}{c}\text { Arouba-Diebold-Scotti } \\
\text { Business Conditions Index (Monthly) }\end{array}$ & $\begin{array}{c}\text { Senior Loan Officer } \\
\text { Opinion Survey (Quarterly) }\end{array}$ \\
\hline \multicolumn{3}{|c|}{ Common sample } \\
\hline IMFFSI & -0.75 & 0.65 \\
\hline KCFSI & -0.83 & 0.80 \\
\hline $\mathrm{NFCl}$ & -0.81 & 0.74 \\
\hline ANFCI & -0.59 & 0.56 \\
\hline STLFSI & -0.78 & 0.70 \\
\hline CLNFCI & -0.73 & 0.57 \\
\hline $\mathrm{BFCl}$ & -0.80 & 0.76 \\
\hline CFSI & -0.67 & 0.65 \\
\hline GSFCI & -0.68 & 0.58 \\
\hline \multicolumn{3}{|c|}{ Full sample } \\
\hline IMFFSI* & -0.56 & 0.68 \\
\hline KCFSI & -0.76 & 0.78 \\
\hline $\mathrm{NFCl}^{*}$ & -0.45 & 0.75 \\
\hline ANFCI* & -0.13 & 0.33 \\
\hline STLFSI & -0.76 & 0.71 \\
\hline CLNFCI & -0.67 & 0.58 \\
\hline $\mathrm{BFCl}$ & -0.76 & 0.78 \\
\hline CFSI & -0.57 & 0.64 \\
\hline GSFCI & -0.66 & 0.55 \\
\hline
\end{tabular}

to define. For these reasons, several private firms, researchers, and central banks have constructed their own FSIs using various series that focus on different forms of systematic risk. In this paper, we surveyed these measures. Generally, we find that the various FSIs are highly correlated. This is probably not surprising because, first, they are all intended to measure effects of shocks that arise in (i) financial markets and spread to the real economy or (ii) the real economy and are propagated in the financial markets. In the latter case, though, shocks that increase financial instability in general would be expected to also affect the macroeconomy through wealth effects, balance sheet effects, or some other transmission mechanism.

The second reason these indexes are highly correlated is that they are generally constructed from overlapping or very similar series. Another distinction concerns the difference between FCIs and FSIs. Since FCIs tend to use more economic indicators, such as loan or debt measures, they tend to produce better forecasts of macroeconomic conditions, on net. However, the forecast errors between the FSIs and FCIs are relatively small. This variation in forecast errors is also a reflection of the available data. Some indexes have observations spanning 30 years or more, whereas others have sample periods less than 20 years. All else equal, estimates based on longer sample periods have an advantage over estimates based on shorter sample periods. 


\section{NOTES}

1 Several other events around this period also contributed to the rise of financial market instability. For example, see the Federal Reserve Bank of St. Louis Financial Crisis Timeline (http://timeline.stlouisfed.org/).

2 See Kindleberger and Aliber (2005) or Reinhart and Rogoff (2008).

$\underline{3}$ One can view this through the lens of the dividend discount model, which posits that the current stock price depends on the current dividend and the assumed growth rate of future dividends relative to the investor's required return on equities.

4 Some indicators use sophisticated statistical techniques to derive an indicator from mixed-frequency data (for example, combining weekly and monthly data).

5 As described later, principal component analysis (PCA) strives to find a common factor that statistically links-for lack of a better term - each of the series used to construct the FSI or FCI. Some FSIs, such as the STLFSI, use the first PC as the index. Unbalanced panels are datasets that begin and/or end on different dates.

6 An on-the-run Treasury security is the most recently issued security traded in the secondary market. A security becomes off-the-run if it is replaced with a newly issued security of the same initial maturity. Most FSls use yields of on-the-run Treasury securities to calculate credit risk and term premiums.

7 Swaptions are options granting their owners the right but not the obligation to enter into an underlying swap.

8 PCA uses an orthogonal transformation to convert a set of observations of potentially correlated variables into a set of values of uncorrelated variables. In other words, the PCs that are constructed (there are more than one) are assumed to be uncorrelated (orthogonal). For each PC, the analysis determines a (weighted) linear combination of the variables that maximizes the percentage of the total variance of each series. The first PC explains the largest percentage of the variance, the second PC the next most, and so on.

9 Technically, they construct CDFs for each of the 11 series used to construct the FSI. The flow of funds sector shares (weights) are then used to aggregate the 11 CDFs.

10 The $\mathrm{NFCl}$ assumes that economic and financial conditions are correlated. The difference between the $\mathrm{NFCl}$ and the ANFCl is that the latter is an isolated measure of financial conditions that are assumed to be uncorrelated with economic conditions. The BFCl values were multiplied by -1 for clearer comparisons with the other indexes examined. Without this change, negative values would indicate periods of high stress.

11 A pseudo out-of-sample forecast uses the sample period that includes the actual data. By contrast, a normal out-ofsample forecast predicts data for variables beyond the actual sample period.

12 For full-sample estimates, this date is the first date that the FSI examined is available. For the common sample, this date is 2000:01 or 2000:Q1.

$\underline{13}$ We do not test whether these differences are statistically significant.

\section{REFERENCES}

Abdymomunov, Azamat. "Regime-Switching Measure of Systemic Financial Stress." Annals of Finance, Online First, March 20, 2012; www.springerlink.com/content/r2n161581366mg54/fulltext.pdf.

Brave, Scott and Butters, R. Andrew. "Monitoring Financial Stability: A Financial Conditions Approach." Federal Reserve Bank of Chicago Economic Perspectives, First Quarter 2011, 35(1), pp. 22-43;

http://qa.chicagofed.org/digital_assets/publications/economic perspectives/2011/1qtr2011_part2_brave_butters.pdf.

Brave, Scott and Butters, R. Andrew. "Diagnosing the Financial System: Financial Conditions and Financial Stress." International Journal of Central Banking, June 2012, pp. 191-239.

Cardarelli, Roberto; Elekdag, Selim and Subir, Lall. "Financial Stress and Economic Contractions." Journal of Financial Stability, June 2011, 7(2), pp. 78-97.

Carlson, Mark; Lewis, Kurt and Nelson, William. "Using Policy Intervention to Identify Financial Stress." Finance and Economics Discussion Series No. 2012-02, Board of Governors of the Federal Reserve System, 2012; www.federalreserve.gov/pubs/feds/2012/201202/201202pap.pdf. 


\section{Kliesen, Owyang, Vermann}

Danninger, Stephan; Balakrishnan, Ravi; Elekdag, Selim and Tytell, Irina. “How Linkages Fuel the Fire: The Transmission of Financial Stress from Advanced to Emerging Economies," in World Economic Outlook: Crisis and Recovery. Chap. 4. Washington, DC: International Monetary Fund, 2009, pp. 139-75; www.imf.org/external/pubs/ft/weo/2009/01/pdf/c4.pdf.

Dudley, William and Hatzius, Jan. "The Goldman Sachs Financial Conditions Index: The Right Tool for a New Monetary Policy Regime." Goldman Sachs Global Economics Paper No. 44, 2000.

Grimaldi, Marianna B. "Detecting and Interpreting Financial Stress in the Euro Area." ECB Working Paper Series No. 1214, European Central Bank, June 2010; www.ecb.europa.eu/pub/pdf/scpwps/ecbwp1214.pdf.

Grimaldi, Marianna B. "Up for Count? Central Bank Words and Financial Stress." Sveriges Riksbank Working Paper Series 252, April 2011, www.riksbank.se/upload/Dokument riksbank/Kat publicerat/WorkingPapers/2011/wp252.pdf.

Hakkio, Craig S. and Keeton, William R. "Financial Stress: What Is It, How Can It Be Measured, and Why Does It Matter?" Federal Reserve Bank of Kansas City Economic Review, Second Quarter 2009, 94(2), pp. 5-50; www.kansascityfed.org/PUBLICAT/ECONREV/pdf/09q2hakkio_keeton.pdf.

Hanschel, Elke and Monnin, Pierre. "Measuring and Forecasting Stress in the Banking Sector: Evidence from Switzerland." BIS Paper No. 22, Bank for International Settlements, April 1, 2005; www.bis.org/publ/bppdf/bispap22a.pdf.

Hansen, Jakob L. "A Risk Index for Euro-Denominated Assets." National Bank of Denmark Working Paper No. 36/2006, May 2006; www.nationalbanken.dk/C1256BE9004F6416/side/B9B35A3789FC790BC125716800455576/\$file/WP 36 2006.pdf.

Hatzius, Jan; Hooper, Peter; Mishkin, Frederic; Schoenholtz, Kermit L. and Watson, Mark W. "Financial Conditions Indexes: A Fresh Look after the Financial Crisis." Presented at the U.S. Monetary Policy Forum, New York, February 26, 2010; http://research.chicagobooth.edu/igm/events/docs/2010usmpfreport.pdf.

Hollo, Daniel; Kremer, Manfred and Lo Duca, Marco. "CISS—A Composite Indicator of Systemic Stress in the Financial System." ECB Working Paper Series No. 1426, March 2012; www.ecb.int/pub/pdf/scpwps/ecbwp1426.pdf.

Illing, Mark and Liu, Ying. "Measuring Financial Stress in a Developed Country: An Application to Canada." Journal of Financial Stability, October 2006, 2(3), pp. 243-65.

Kindleberger, Charles P. and Aliber, Robert. Manias, Panics, and Crashes: A History of Financial Crises. Fifth Edition. Hoboken, NJ: John Wiley \& Sons, 2005.

Kliesen, Kevin L. and Smith, Douglas C. "Measuring Financial Market Stress." Federal Reserve Bank of St. Louis National Economic Trends, January 2010; http://research.stlouisfed.org/publications/net/20100101/cover.pdf.

Lo Duca, Marco and Peltonen, Tuomas A. "Macro-Financial Vulnerabilities and Future Financial Stress: Assessing Systemic Risks and Predicting Systemic Events." ECB Working Paper Series No. 1311, European Central Bank, March 2011; www.ecb.int/pub/pdf/scpwps/ecbwp1311.pdf.

Louzis, Dimitrios P. and Vouldis, Angelos T. "A Financial Systemic Stress Index for Greece." Presented at the First Conference of the Macro-prudential Research (MaRs) network of the European System of Central Banks in Frankfurt am Main, October 2011;

www.ecb.int/events/conferences/shared/pdf/net mar/Session5 Paper1_Louzis Vouldis.pdf?0a69933005a2042412 8db8ebdf6310c7.

Macroeconomic Advisers. "A Combined Monetary, Financial, and Fiscal Conditions Index." Technical Notes, December 4, 2003; www.macroadvisers.com/content/Monetary,\%20Financial,\%20and\%20Fiscal\%20Conditions\%20Index.pdf.

Morales, Miguel and Estrada, Dairo. "A Financial Stability Index for Colombia." Annals of Finance, October 2010, 6(4), pp. 555-81.

Nelson, William R. and Perli, Roberto. "Selected Indicators of Financial Stability," in Risk Management and Systemic Risk. Frankfurt, Germany: European Central Bank, 2007, pp. 343-72; www.ecb.int/pub/pdf/other/riskmeasurementandsystemicrisk200704en.pdf.

Oet, Mikhail V.; Eiben, Ryan; Bianco, Timothy; Gramlich, Dieter and Ong, Stephen J. "The Financial Stress Index: Identification of System Risk Conditions." Working Paper No. 1130, Federal Reserve Bank of Cleveland, November 2011, www.clevelandfed.org/research/workpaper/2011/wp1130.pdf. 
Reinhart, Carmen and Rogoff, Kenneth. This Time Is Different: Eight Centuries of Financial Folly. Princeton, NJ: Princeton University Press, 2009.

Rosenberg, Michael. Financial Conditions Watch, Global Financial Market Trends and Policy. Bloomberg LLP, September 11, 2009. www.ssc.wisc.edu/ mchinn/fcw sep112009.pdf.

Sandahl, Johannes F.; Holmfeldt, Mia; Rydén, Anders and Strömqvist, Maria. "An Index of Financial Stress for Sweden." Sveriges Riksbank Economic Review, July 10, 2011, 2011(2), pp. 49-67;

www.riksbank.se/Upload/Rapporter/2011/POV 2/er 20112 forsssandahl holmfeldt ryden stromqvist.pdf.

Yiu, Matthew S.; Ho, Wai.-Yip Alex and Jin, Lu. "A Measure of Financial Stress in Hong Kong Financial Market: The Financial Stress Index." Hong Kong Monetary Authority Research Note No. 02/2010, March 3, 2010; www.hkma.gov.hk/media/eng/publication-and-research/research/research-notes/RN-02-2010.pdf.

\begin{tabular}{|c|c|}
\hline \multicolumn{2}{|c|}{$\begin{array}{l}\text { APPENDIX A } \\
\text { Start Dates for Full Series }\end{array}$} \\
\hline Index & Start Date (Month/Year) \\
\hline CFSI & $1 / 1994$ \\
\hline $\mathrm{BFCl}$ & $1 / 1994$ \\
\hline CLNFCI & $6 / 1994$ \\
\hline GSFCl & $1 / 2000$ \\
\hline ANFCI & $1 / 1979$ \\
\hline $\mathrm{NFCl}$ & $1 / 1979$ \\
\hline STLFSI & $12 / 1993$ \\
\hline IMFFSI & $12 / 1980$ \\
\hline KCFSI & $2 / 1990$ \\
\hline
\end{tabular}

\begin{tabular}{|lccc|}
\hline APPENDIX B & \multicolumn{3}{l}{} \\
Lag Lengths for Forecasts* & & \\
& \multicolumn{3}{c}{ Dependent variable } \\
\cline { 2 - 4 } Index & IP & GDP & Wilshire \\
\hline CFSI & 2 & 2 & 1 \\
BFCl & 2 & 2 & 1 \\
CLNFCI & 1 & 2 & 1 \\
GSFCI & 2 & 2 & 2 \\
ANFCI & 3 & 2 & 1 \\
NFCl & 3 & 2 & 2 \\
STLFSI & 2 & 2 & 1 \\
IMFFSI & 3 & 3 & 1 \\
KCFSI & 4 & 2 & 1 \\
*Industrial production (IP) and Wilshire lag lengths are months; \\
GDP lag lengths are quarters.
\end{tabular}


Close

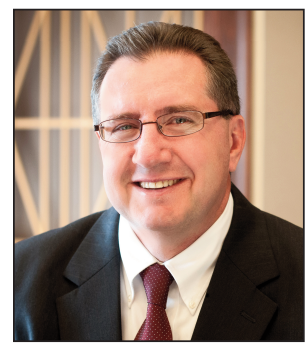

\section{Kevin L. Kliesen}

Research officer and economist, Federal Reserve Bank of St. Louis

http://research.stlouisfed.org/econ/kliesen/

\section{Research Focus}

Kevin Kliesen's research focuses on the analysis of macroeconomic conditions, the effects of energy prices on the economy, labor productivity, and fiscal policy; he also provides reports on economic and business conditions to assist the Bank president and Board of Directors.

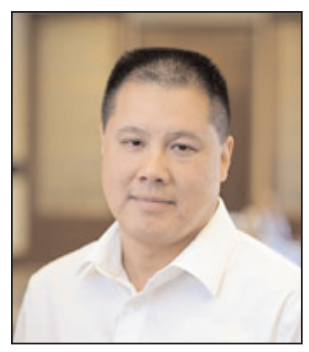

\section{Michael T. Owyang}

Research officer and economist, Federal Reserve Bank of St. Louis

http://research.stlouisfed.org/econ/owyang/

\section{Research Focus}

Michael Owyang's main areas of research are in Bayesian econometrics, time-series econometrics, and forecasting.

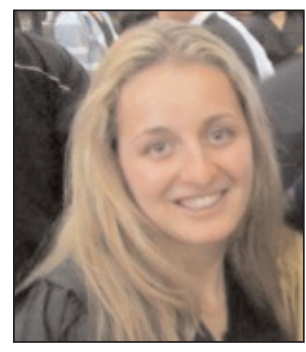

\section{E. Katarina Vermann}

Research associate, Federal Reserve Bank of St. Louis

\section{Research Focus}

E. Katarina Vermann currently assists economists Michael Owyang and Subhayu Bandyopadhyay with their research. Her research interests also include labor, health, and urban economics with a focus on public policy. 